\title{
Political Institutions and Policy Outcomes: What are the Stylized Facts?*
}

\author{
Torsten Persson ${ }^{\dagger} \quad$ Guido Tabellini ${ }^{\ddagger}$ \\ This version: February 1, 2001 \\ First Draft: July 2000.
}

\begin{abstract}
We investigate the effect of electoral rules and political regimes on fiscal policy outcomes in a panel of 61 democracies from 1960 and onwards. In presidential regimes, the size of government is smaller and less responsive to income shocks, compared to parliamentary regimes. Under majoritarian elections, social transfers are smaller and aggregate spending less responsive to to income shocks than under proportional elections. Institutions also shape electoral cycles: only in presidential regimes is fiscal adjustment delayed until after the elections, and only in proportional and parliamentary systems do social transfers expand around elections. Several of these empirical regularities are in line with recent theoretical work; others are still awaiting a theoretical explanation.
\end{abstract}

${ }^{*}$ We are grateful for useful comments from Alberto Alesina, Per-Anders Edin, Felix Oberholzer-Gee, David Strömberg, Jakob Svensson, and from participants in seminars at the Bank of England, Berkeley, Bonn, the European Central Bank, Stanford, Stockholm, UCL, Uppsala, Warwick, and conferences in Toulouse and Lugano. We would also like to thank Christina Lönnblad for editorial assistance and Gani Aldashev, Alessia Amighini, Thomas Eisensee, Giovanni Favara, Alessandro Riboni, and Francesco Trebbi for research assistance at various stages of the project. This research is supported by a TMR-grant from the European Commission, and by grants from Bocconi University, MURST, and the Swedish Council for Research in the Humanities and Social Sciences.

${ }^{\dagger}$ IIES, Stockholm University; London School of Economics; CEPR; NBER.

$¥$ IGIER, Bocconi University; CEPR; Ces-Ifo. 


\section{Introduction}

A recent literature on comparative politics has asked how political institutions might shape economic policy. In particular, a number of theoretical contributions by economists predict that electoral rules and political regimes systematically influence fiscal policy outcomes: see Persson and Tabellini (2000) for a survey. But empirical work is still scant. Whereas a large and interesting literature discusses how constitutional features of state and local governments correlate with policy outcomes (see for instance Bohn and Inman, 1996, Pommerhene, 1990, Feld and Matsusaka, 2000), only a few empirical studies have compared fiscal policy in large samples of countries governed by different electoral rules or political regime. Some recent exceptions are Poterba and Von Hagen (1999), Milesi-Ferretti, Perotti and Rostagno (2000), and Persson and Tabellini (1999). ${ }^{1}$

Political scientists have done extensive empirical work on comparative politics for a long time. But their focus has been on political phenomena, such as the number of parties, the frequency of elections, or the attributes of governments under different constitutions, and does not touch on fiscal policy. Castels (1998) and Lijphart (1999) are among the rare exceptions, but their analyses are confined to correlations and bivariate regressions, relating a few economic policy outcomes to constitutional features. As a result, very little is known about whether and how fiscal policy varies across political institutions, particularly when the analysis is extended to non-OECD countries.

We try to fill this gap. Specifically, we try to establish some stylized facts regarding the mapping from electoral rules and political regimes to policy outcomes. We look exclusively at the effects on fiscal policy: the size and composition of government spending and government deficits. A companion paper (Persson, Tabellini and Trebbi, 2000) studies the incidence of corruption across different political institutions. While some of our estimates aim at direct tests of specific hypotheses, we also go beyond such tests in our search for systematic relationships in the data.

The political constitution seems to matters a great deal for policy. We find striking similarities between presidential regimes and majoritarian electoral rules. Both institutions are associated with smaller governments, compared to parliamentary and proportional systems. The quantitative effect is particularly large and robust for presidential regimes and for the growth of government over time:

\footnotetext{
${ }^{1}$ Tanzi and Schuknecht (2000) provide an extensive and detailed description of fiscal policy in a very large sample of countries, but they do not ask how policy varies across constitutions.
} 
towards the end of our sample, presidential regimes have a smaller size of government of about $10 \%$ of GDP. How government spending reacts to economic and political events is also systematically correlated with institutions. Presidential and majoritarian systems react in a more dampened and less persistent fashion to income shocks, compared to proportional and parliamentary systems. This could reflect a different composition of spending (social transfer programs tend to be smaller in presidential and majoritarian democracies), or a different response of the collective decision process to changing economic circumstances. The peculiar dynamic and stochastic properties of government spending are also reflected in budget deficits, which are smaller in absolute value and react less to shocks in presidential and majoritarian democracies. Finally, electoral cycles in fiscal policy are also institution-dependent. In all countries, tax revenue goes down (as a fraction of GDP) at the time of the elections. But in presidential regimes, we also observe spending cuts and painful fiscal adjustments postponed until after the election. And in parliamentary regimes with proportional elections, social transfers are boosted before and after the elections. While some of these findings are consistent with the predictions of existing theories, others indicate interesting puzzles.

Section 2 provides a background, by sketching some of the main ideas in recent theoretical work. Section 3 describes our data set, in which the measures of fiscal policy outcomes as well as political institutions are clearly motivated by the theory. Section 4 explains our statistical methodology. Section 5 presents our empirical results. Section 6 summarizes our results and makes suggestions for future research.

\section{Motivation}

Why would political institutions shape economic policy? The basic idea is that policy choices entail conflicts among different groups of voters, between voters and politicians (agency problems), and among different politicians. The way these conflicts are resolved, and thus what fiscal policy we observe, hinges on the political institutions in place. Political constitutions are like incomplete contracts. They do not impose specific policy choices. Rather, they spell out how the "control rights" over policy are acquired through elections, and how they can be exercised in the course of the legislature. Thus, which politicians get the power to make policy decisions is determined by voters, but is crucially influenced by rules for elections. Policy choices are made by elected politicians, but are crucially influ- 
enced by rules for rule-making and legislation; that is, what political scientists call the regime type.

As already mentioned in the introduction, a recent theoretical literature has tried to model the consequences of these institutions for fiscal policy choices. It has focused on the level of taxation and on the composition of spending, distinguishing between three types of programs: (i) broad, non-targeted programs benefiting large groups of the electorate; (ii) narrow, targeted programs benefiting small groups; (iii) programs benefiting mainly incumbent politicians. Political institutions are modeled as the rules for a specific policy game, where voters elect political representatives who in turn take decisions on fiscal policy. In this literature, alternative constitutions amount to alternative rules for how to play this game and "comparative politics" amounts to comparing equilibrium outcomes. Below, we describe the main ideas in a handful of recent studies which have applied this comparative politics approach. We just outline the results, emphasizing the specific predictions regarding the size and composition of public spending. Interested readers can find the details in Persson and Tabellini (2000, Part III).

Electoral rules Legislative elections around the world differ in several dimensions. The political science literature emphasizes two: district size and the electoral formula. ${ }^{2}$ District size simply determines how many legislators acquire a seat in a voting district. The electoral formula determines how votes are translated into seats. Under plurality rule, only the individual(s) winning the highest vote share(s) get the seat(s) in a given district, whereas proportional representation (PR) instead awards seats to parties in proportion to their vote shares. Existing theoretical papers have formulated specific predictions about the effects of district size and the electoral formula on policy choices in political equilibrium.

Consider district size first. Persson and Tabellini (1999), (2000, Ch. 8) predict that it influences the composition of government spending. They study two party electoral competition. Larger voting districts diffuse electoral competition, inducing both parties to seek support from broad coalitions in the population. Smaller districts instead steer electoral competition towards narrower, geographical constituencies. With small districts, typically a party is a sure winner in some districts and a sure loser in others. Electoral competition is thus concentrated only in some pivotal districts, and both parties have strong incentives to target

\footnotetext{
${ }^{2}$ Other aspects of the electoral system that differ across countries include thresholds for representation and the rules governing party lists. See e.g Cox (1997) and Blais and Massicotte (1996) for recent descriptions of variations in electoral rules across countries.
} 
redistribution towards such districts. Clearly, broad programs are more effective in seeking broad support and targeted programs more effective in seeking narrow support. An example of spending that benefits broad coalitions and cannot easily target specific district is welfare spending, which is thus predicted to grow with district size. Milesi-Ferretti, Perotti and Rostagno (2000) reach a similar conclusion, but with a different reasoning. They argue that with large electoral districts legislators mainly represent socio-economic groups in the population, while with small districts they mainly represent groups in specific geographic locations. Thus, with large electoral districts government policy targets powerful socio-economic groups, while with small districts it targets powerful geographical groups.

How about the electoral formula? One effect of the winner-takes-all property of plurality rule is to reduce the minimal coalition of voters needed to win the election. Under single-member districts and plurality, a party can win with only 25 $\%$ of the national vote: $50 \%$ in $50 \%$ of the districts. Under full PR it needs $50 \%$ of the national vote; politicians are thus induced to internalize the policy benefits for a larger segment of the population, which lead them to put stronger emphasis on broad programs than under plurality (Lizzeri and Persico, 2000, Persson and Tabellini, 2000, Ch. 9).

The electoral formula matters for a second reason. Under plurality rule, voters choose among individual candidates. Under PR, they choose among party lists. Such lists may dilute the incentives for individual incumbents to perform well, because they entail a double layer of delegation: individual legislators are accountable to parties, who in turn are accountable to voters. Persson and Tabellini (2000, Ch. 9) examine the policy consequences in a Holmström (1982)-style, career-concern models. They derive the predictions that opportunistic electoral cycles, showing up in spending or taxes, are weaker under PR. The reason is that incumbents' career concerns are stronger under plurality rule and are at their strongest just before elections.

Even though these two features of electoral rules have logically distinct consequences, they are highly correlated across real-world electoral systems. Some systems can be described as majoritarian, combining small voting districts with plurality rule. Archetypes here are elections to the UK parliament or the US Congress, where the candidate collecting the largest vote share in a district gets the single seat. Some electoral systems are instead decidedly proportional, combining large electoral districts with proportional representation. Archetypes are the Dutch and Israeli elections, where parties obtain seats in proportion to their vote shares in a single national voting district. While we find some intermediate 
systems, most countries fall quite unambiguously into this crude, binary classification. Fortunately, the different predictions about composition above tend to reinforce each other. Thus, proportional elections - with larger districts and PR should be associated with broader programs and larger welfare states, and weaker electoral cycles.

A pitfall of the recent theoretical literature is that it has neglected the implications of the electoral rule on the party structure. Many empirical contributions by political scientists deal with precisely this aspect (see for instance Lijphart, 1994,1999), emphasizing that majoritarian elections are associated with a smaller number of parties. Electoral rules may thus also shape policy indirectly, through the party structure. On the one hand, proportional elections entail lower barriers to entry for new parties catering to specific groups of voters. On the other hand, majoritarian (parliamentary) systems are more likely to produce singleparty majority governments, whereas coalition governments are more likely under proportional elections. The likely consequences for economic policy have been stressed in several studies. First, Austen-Smith (2000) takes party structure as exogenous, but assumes that fewer parties are represented under plurality rule (two parties) than under PR (three parties). He then shows that the interaction between elections, redistributive taxation, and the formation of economic groups is likely to produce politico-economic equilibria with higher taxation under PR than under plurality. Second, the common-pool problem in fiscal policy might be more pervasive under coalition governments. Kontopoulos and Perotti (1999) have argued that this could lead to larger government spending, and Scartascini and Crain (2001) provide further evidence of this effect. Third, as coalition governments have more veto players, the status-quo bias in the face of adverse shocks could be more pronounced (Roubini and Sachs, 1989, Alesina and Drazen, 1991). Fourth, government crises are more likely and indeed empirically more frequent under proportional elections, which could lead to greater policy myopia and larger budget deficits (Alesina and Tabellini, 1990, Grilli, Masciandaro and Tabellini, 1991). Fifth, large swings in the ideological preferences of governments as a result of the elections are less likely under coalition governments. Alesina, Roubini and Cohen (1997) suggest that coalition governments (and thus proportional elections) correlate with less pronounced "partisan" cycles after the elections. Not all these ideas have been fleshed out with the same analytical rigor as in the more recent theoretical literature. But they can certainly suggest interpretations for the empirical findings we report below. 
Regime types Two crucial aspects of the legislative regime concern the powers over legislation: to make, amend, or veto policy proposals. The first concerns the separation of those powers across different politicians and offices. The second concerns the maintenance of powers; in particular, whether the executive needs sustained confidence by a majority in the legislative assembly.

As in the case of electoral rules, real-world regimes fall quite unambiguously into a crude two-way classification with regard to these aspects. Presidential regimes typically have separation of powers, between the president and Congress, but also between congressional committees that hold important proposal (agendasetting) powers in different spheres of policy (as in the US). But they do not have a confidence requirement: the executive can hold on to his powers without the support of a majority in Congress. In parliamentary regimes the proposal powers over legislation are instead concentrated in the hands of the government. Moreover, the government needs the continuous confidence of a majority in parliament to maintain those powers throughout an entire election period.

Why should separation of powers matter for policy? A classical argument is that checks and balances constrain politicians from abusing their powers. Persson, Roland, and Tabellini $(1997,2000)$ formally demonstrate this old point in models where incumbents are held accountable by retrospective voters. The upshot is that we should expect weaker political accountability in parliamentary regimes, resulting in higher rents and higher taxes.

The confidence requirement has other effects. Parties supporting the executive hold valuable proposal powers which they risk losing in a government crisis. Therefore, a confidence requirement creates strong incentives to maintain a stable majority when voting on policy proposals in the legislature. The absence of a confidence requirement instead leads to more unstable coalitions and less discipline within the majority.

Building on this idea of "legislative cohesion", due to Diermeier and Feddersen (1998), Persson, Roland and Tabellini (2000) derive two additional predictions. In parliamentary regimes, a stable majority of legislators tends to pursue the joint interest of its voters. Spending in parliamentary regimes thus optimally becomes directed towards broad programs that benefit a majority of voters, such as social security and welfare spending. In presidential regimes, instead, the (relative) lack of such a majority tends to pit the interests of different minorities against each other for different issues on the legislative agenda. As a result, the allocation of spending targets powerful minorities, typically the constituency of the powerful officeholders such as the heads of committees in Congress. In 
parliamentary regimes, the stable majority of incumbent legislators, and its voters, become prospective residual claimants on additional revenue. Both favor high taxes and high spending. In presidential regimes, on the other hand, majorities are not residual claimants on revenue and therefore resist high spending. These forces produce larger governments (higher taxes) and broader social transfer programs in parliamentary regimes.

Summary Let us summarize the main predictions with the help of Table 1. According to the theory, presidential regimes have smaller governments than parliamentary regimes and less spending on broad social security and welfare programs. Under majoritarian elections, we should observe less spending on broad social security and welfare programs than under proportional elections. The commonpool argument (and the model suggested by Austen-Smith, 2000) suggests that the electoral rule could also matter for the size of government, with proportional elections associated with bigger governments. These are all cross-sectional predictions, in that they have been derived by comparing equilibria in static models.

Some of the theoretical ideas summarized above also have dynamic predictions. Models stressing the greater status-quo bias and myopia of coalition governments would predict that proportional-parliamentary systems have larger steady-state debts, and - during the transition - larger budget deficits. The stronger incentive to perform under majoritarian elections suggest that majoritarian-parliamentary countries might have more pronounced electoral cycles than proportional-parliamentary countries. We have no theoretical prior about deficits and electoral cycles in presidential regimes. Similarly, to derive specific implications about the reaction to shocks under these systems, one would need a more precise dynamic model, including detailed assumptions about status-quo policy.

\section{Data}

In putting our data set together, we have relied on the theory described in Section 2 for the measurement of political institutions and fiscal policy outcomes. Data availability also determines the sample, which comprises yearly data for 61 countries over almost four decades (1960-98). This panel includes a large number of economic, social and political variables. Because of missing data and our rules for sampling (described next), however, it is an unbalanced panel. The sources for all the data used in the paper are listed in the Data Appendix. 
Which countries? The theory suggests that we should confine our study to countries with democratic political institutions. Here, we have relied on a wellknown classification by Freedom House. The so-called Gastil indexes of political rights and civil liberties vary on a scale from 1 to 7 , low values being associated with better democratic institutions. ${ }^{3}$ To assess a country's democratic status in a particular year, we took the average of these two indexes. The Gastil indices are available annually, from 1972 and onwards. For the earlier period, we follow Barro (1998) and rely on a measure compiled by Bollen (1990), available every five years (which we re-scaled onto a scale from 1 to 7 ).

We use three different rules for including countries in the sample, and we report results for all three samples. The most permissive one is to include a country from the point in time when it first obtains a Gastil-score of 5 or lower, but not exclude it from the sample in the wake of a temporarily higher score reflecting restricted democratic rights. This rule permits a maximum of 61 countries in the sample. We refer to this sample of countries as the Broad sample. Our Default sample relies on a more restrictive rule, namely to exclude a country from the sample in any year when it has a Gastil score of 3.5 or lower. This rule cuts the number of annual observations in the panel by about 350. As an example, the more restrictive rule temporarily excludes countries like Turkey (intermittently) and Argentina (in the 80s) after their first entry into the panel. A yet more restrictive rule identifies a Narrow sample as those countries and years where the Gastil score is less than or equal to 2. Here we lose many more observations, particularly in the early part of the sample, since we are really restricting attention to well functioning democracies. As in the Default sample, a few countries enter and exit from the sample at different points of time. Throughout, we treat these censored observations as randomly missing and do not attempt to model sample selection. The three samples are listed in Table 2, along with our classification of regime types and electoral rules (see the next subsection). As an example, Chile enters the Broad sample for the full sample period, exits from the Default sample between 1974 and 1988, and is only included in the Narrow sample from 1991 and onwards.

Which political institutions? Following the theoretical discussion in Section 2, we classify electoral rules and regime types by means of two indicator (dummy) variables: $M A J$ and PRES. Majoritarian countries $(M A J=1)$ are those that

\footnotetext{
${ }^{3}$ According to the index, countries scoring 1 or 2 are "free", countries scoring from 3 to 5 "semi-free", while countries scoring 6 or 7 are "non-free".
} 
relied exclusively on plurality rule in its previous most recent election to the legislature (lower house), the others are proportional $(M A J=0)$. Relying on district size rather than the electoral formula would produce a similar but not identical classification. ${ }^{4}$ In some sensitivity analysis, not reported below, we have also allowed for a finer partition that discriminates between three types: majority, proportional and mixed systems. But when it comes to the effect on fiscal policy outcomes, the effects of mixed and proportional systems appear to be similar.

With regard to regime type, we classify as presidential $(P R E S=1)$ countries where the executive is not accountable to the legislature through a vote of confidence, and those where it is as parliamentary $(P R E S=0)$. Thus, we try to capture the institutions producing stable legislative majorities, as discussed in Section 2. (We have not tried to classify countries on the basis of the checks and balances entailed in the separation of powers granted by their constitutions.) In building this index we had to assess whether or not the office of the President has executive powers in the realm of fiscal policy. If not, and if the government is instead accountable to Parliament through a confidence requirement, the country is classified as a parliamentary regime. In evaluating the executive powers of the President, we mainly relied on Shugart and Carey (1992).

There are very few changes over time in these classifications (PRES does not vary at all, whereas $M A J$ displays time variation in France (which had a brief period of proportional representation in 1985-86) and in Cyprus only. This stability reflects an inertia of political institutions sometimes called an "iron law" by political scientists. The lack of time variation is unfortunate in that it provides us with almost no "experiments" in the form of regime changes. But it is also an indication that it may be correct to treat institutions as given by history, and not influenced by reverse causation going from policy outcomes to institutions.

Figure 1 illustrates the institutional variation across countries in 1995. The colored portions of the map represent the 61 countries in the sample. Striped areas indicate presidential regimes $(P R E S=1)$, solid areas parliamentary regimes $(P R E S=0)$. Darker shade indicates majoritarian elections $(M A J=1)$, lighter shade proportional elections $(M A J=0)$. The least common system is the US-style (gray striped) combination of a presidential regime with majoritarian elections, with only five countries. But each of the other three combinations is well represented in the sample. In the last two columns of Table 2, we report the values of $M A J$ and PRES (averaged over time) for all the countries in our samples.

\footnotetext{
${ }^{4}$ Persson and Tabellini (1999) rely on district size, classifying all countries with an average district size below two (seats per district) as majoritarian, others as proportional.
} 
As the map illustrates, using theory in the classification sometimes produces results contrary to popular perception. According to our classification, parliamentary regimes include France, Portugal and Finland, with a directly elected president, but where the government is accountable to the elected assembly and the president has no or little executive powers over fiscal policy. Conversely, the presidential regimes include Switzerland, where there is no popularly elected president but the permanent coalition executive cannot be brought down by the legislative assembly. ${ }^{5}$

Even a cursory look at the map reveals that our institutional classification does not produce a random outcome. The electoral rule does not exhibit a particular pattern in terms of development, but most Anglo-Saxon countries and countries of British colonial origin have $M A J=1$ while most of Europe and South America has $M A J=0$. Presidential regimes are largely confined to non-OECD countries (among the OECD-countries, only the US and Switzerland have PRES = 1). Moreover, many presidential regimes happen to be in Central and South America, though the sample also includes several non-presidential Caribbean countries. Other presidential regimes are Nepal, the Philippines, and Senegal.

This non-random pattern of constitutions in our sample raises a fundamental question: can we really treat the constitution as exogenous in the empirical analysis that follows? It could very well be that countries self-select into constitutions on the basis of historical variables and collective preferences that also influence policy decisions. To take care of this problem, in the regressions reported below we try to control for a large set of historical and geographical variables that might also explain the constitutional origin of a country. But in this paper we do not seek to explain the constitutional choice itself. In a companion paper (Persson, Tabellini and Trebbi, 2000), however, we also rely a non-parametric estimator that explicitly allows for endogenous selection of countries into alternative electoral rules.

Which fiscal policy outcomes? We include fiscal-policy outcomes as suggested by the theory. Thus, we measure the size of government mainly by the ratio of central government spending (inclusive of social security) to GDP, expressed as a percentage $(C G E X P)$. But we have also looked at central government revenues and at general government spending, both as a percentage of GDP. For the composition of government spending we use two measures: social security and welfare

\footnotetext{
${ }^{5}$ The Swiss constitution indeed resembles the US constitution in many respects beyond the absence of a confidence requirement.
} 
spending (by central government) as a percentage of GDP $(S S W / G D P)$, or as a ratio to spending on goods and services $(S S W / G D S)$. The presumption is that broad transfer programs, like pensions and unemployment insurance, are much harder to target towards narrow geographic constituencies compared to spending on goods and services. Finally, we look at the size of the budget surplus of the central government, as a percent of GDP (SURPLUS).

The measures of size and deficits are available for most OECD countries for the entire period 1960-98. For many developing countries availability is limited to the period from the 1970s and onward. Similarly, the measures of the composition of spending do not become available until the early 1970s. The statistical source for all these variables is the IMF. For the size of government, budget deficits and debts, we rely on IFS data which is available for a longer time series. General government spending and the composition of spending are instead extracted from the GFS database.

These policy measures vary a great deal, both across time and countries. As an illustration consider Figure 2, which shows the size of government as measured by central expenditures in our sample. In the figure, we see that government expenditure in a typical year ranges from below 10 percent of GDP to above 50 percent. We also see how the distribution drifts upwards over time, reflecting growth in the average size of government - the curve in the graph - by about 8 percent of GDP from the 1960s to the mid 1990s. Most of this growth takes place in the 1970s and 80s.

Our measures of the composition of spending also show a wide distribution where spending on social security and welfare drifts upwards at least until the mid 1980s. The deficits are also widely distributed across countries, with average deficits having their peak in the period from the mid 70s to the mid 80s.

Given that we mainly rely on central government spending in our analysis, a natural question is whether this matters. Suppose, for instance, that presidential regimes were more decentralized than parliamentary regimes. By looking at central government spending only, we might than mistakenly interpret a lower size of central government in presidential countries as due to the regime type, while it could simply reflect their lower degree of centralization. Fortunately, however, centralization of spending is not systematically correlated with the political constitution, at least in the 41 countries and in the years were data on both levels of government are available - see the last subsection below. 
Which socio-economic controls? The theory we have surveyed in Section 2 should clearly be understood as providing ceteris paribus predictions about fiscal policy. Therefore, we control for other variables likely to shape government outlays and revenues. Specifically, we always include in our regressions the level of development, measured by the log of real per capita income $(L Y H)$, a measure of openness (TRADE), defined as exports plus imports over GDP, and two variables measuring the demographic composition, defined as the percentages of the population between 15 and 64 years of age (PROP1564), and above 65 years of age (PROP65), respectively. These variables have been show to correlate with measures of fiscal policy in previous studies, such as Cameron (1978), Rodrik (1998), and Persson and Tabellini (1999). We will refer to this basic set of controls by $X_{1}$.

Depending on the specification, the dependent variable and the frequency of sampling, we have also included several other variables, such as the price of oil in US dollars $(O I L)$, income shocks, measured either as the growth rate of real GDP or as the log difference between real GDP and its trend computed with the Hodrick-Prescott filter ( $Y S H O C K$ ), and levels of government debt, as a percentage of GDP $(D E B T)$.

To cope with the non-random pattern of constitutions noted above, we also use several indicator variables, measuring geographic locations, legal origin, colonial origins, federal or unitary structure, and election dates. All these variables are defined more precisely in the Data Appendix.

Summary statistics Tables $3 a$ and $3 b$ display the correlation matrix between our main variables of interest. Table $3 a$ shows cross-country correlations, with data averaged over the full period for which we have observations for each variablecountry pair. Table $3 b$ instead pools the yearly observations for all countries. Both tables display a similar pattern. While the electoral rule appears uncorrelated with the socio-economic controls, the regime type is much more correlated with the level of development and the demographic structure, in line with our previous observation that most presidential regimes are outside the OECD countries. We also see that presidential regimes are associated with smaller governments and smaller social security and welfare spending, whereas majoritarian electoral rules are correlated with larger surpluses and smaller social security and welfare spending. These correlations are not inconsistent with the theoretical predictions summarized in Table 1.

As Table $3 a$ shows the variable CENTRAL - defined as the ratio of central 
to general government expenditure - is neither systematically related to our measures of institutions, nor to the overall size of government. (This variable can be constructed for 41 countries between the early 1970s and the late 1980s.) The lack of correlation with political institutions reassures us that focusing on central government spending will not systematically bias our results.

\section{Methodology}

Our empirical analysis is certainly motivated by theory. We aim as much at establishing empirical regularities, however, as at testing hypotheses derived from specific models. That is, we would like to succinctly describe systematic relations in the data, establishing some stylized facts about the effect of institutions on policy outcomes. For this reason, we follow an eclectic approach.

A general formulation The regressions we estimate in the paper are all derived from the following general formulation:

$$
y_{i t}=\alpha_{i}+\boldsymbol{\gamma}_{i} \mathbf{s}_{i t}+\boldsymbol{\beta}_{i} \mathbf{q}_{t}+\boldsymbol{\delta} \mathbf{x}_{i t}+\boldsymbol{\eta} \mathbf{z}_{i}+u_{i t} .
$$

In (1), $y_{i t}$ denotes a specific policy outcome in country $i$ in year $t$ and Greek boldface letters denote vectors of unknown parameters to be estimated, possibly varying across countries or groups of countries. We allow for a country-specific average, $\alpha_{i}$. Policy can be influenced directly by the institutions $\mathbf{z}_{i t}$, concretely the two dummy variables $M A J$ and PRES. It can also be affected by vectors of socio-economic control variables: $\mathbf{s}_{i t}$ and $\mathbf{q}_{t}$ denote country-specific and common variables the slope coefficients of which are allowed to vary, whereas the variables in $\mathbf{x}_{i t}$ are instead constrained to have the same impact on all countries. Finally, $u_{i t}$ is an unobserved error term.

We want to test two sets of hypotheses. The first is whether institutions have a direct impact on policy outcomes, which is really what most of the theory discussed in Section 2 was about. The nul hypothesis corresponding to this question can be formulated as:

$$
H_{0}^{D}: \boldsymbol{\eta}=0
$$

Cross-section regressions To see how we may test the first hypothesis, $H_{0}^{D}$, we take time averages of (1) within each country, and rewrite it as (a bar over a 
variable denotes a time average):

$$
\bar{y}_{i}=\left(\alpha_{i}+\gamma_{i} \overline{\mathbf{s}}_{i}+\boldsymbol{\beta}_{i} \overline{\mathbf{q}}\right)+\boldsymbol{\eta} \overline{\mathbf{z}}_{i}+\boldsymbol{\delta} \overline{\mathbf{x}}_{i}+\bar{u}_{i} .
$$

Equation (2) can be estimated on cross-sectional data with standard methods, with the estimated intercept capturing the effect of all variables within brackets. The $t$-statistic on PRES and MAJ is then a test of the nul hypothesis $H_{0}^{D}$.

Time variation in the data Such cross-sectional estimates have the advantage of being closely related to some existing theories. But they do not exploit the time variation in the data. Moreover, they might be subject to simultaneity problems in the form of omitted-variable bias: as discussed above some forces selecting political institutions in historical times may also drive economic policy outcomes. The institutional variation over time is too small to circumvent this problem of "historical omitted variables" by conventional fixed-effects, panel-data estimation. For practical purposes, $\mathbf{z}_{i t}$ is given by a constant, $\mathbf{z}_{i}$, equal to the time average $\overline{\mathbf{z}}_{i}$. Thus, we cannot separately estimate the effects on policy of a country's institutions, $\mathbf{z}_{i}$, and other time-invariant, country-specific features, $\alpha_{i}$.

For this reason we also ask a slightly different question, namely whether political institutions have an indirect, or non-linear, effect on policy. In particular, we ask whether different electoral rules and political regimes induce different policy responses to economic and political events. Even if the cross-section results might be plagued by simultaneity, it is much less plausible that the forces selecting the observed political institutions in historical times would be systematically correlated with the response to economic and political events during our recent sample period.

The nul hypothesis corresponding to this second question is whether countries with different values of $\mathbf{z}_{i}$ nevertheless have the same coefficients $\boldsymbol{\gamma}$ and $\boldsymbol{\beta}$ in (1):

$$
H_{0}^{I}: \gamma_{i}=\gamma_{j} \quad \text { and } / \text { or } \quad \boldsymbol{\beta}_{i}=\boldsymbol{\beta}_{j} \quad \text { even if } \quad \mathbf{z}_{i} \neq \mathbf{z}_{j}
$$

Recall, however, that the specific theoretical contributions discussed in Section 2 , are either static, or have rather loose predictions concerning the link between institutions and policies. Most of our tests for indirect effects (non-linearities) should thus be seen as a search for empirical regularities rather than tests of specific predictions. 
Non-observable common events There are various ways of testing $H_{0}^{I}$, that is, the absence of an indirect effect of institutions. It is plausible that a set of common economic and political events have affected fiscal policy in all countries. We need only think about the worldwide turn to the left in the late 1960s and 70s, or the productivity slowdown and oil shocks in the 1970s and 80s. But suppose we do not want to commit to, or cannot observe, all such events. Blanchard and Wolfers (2000) suggest a simple statistical method for estimating how labor-market institutions might influence the adjustment of unemployment to unobservable shocks. Milesi-Ferretti, Perotti and Rostagno (2000) indeed apply this method to study how the proportionality of electoral systems affects policy in the OECD countries.

Assume that the response to observable country-specific variables is the same in all countries, $\gamma_{i}=\gamma_{j}$ in (1). Then we can lump all the variables in $\mathbf{s}_{i t}$ together with those in $\mathbf{x}_{i t}$ and rewrite (1) as:

$$
y_{i t}=\left(\alpha_{i}+\boldsymbol{\eta} \mathbf{z}_{i}\right)+\left(1+\boldsymbol{\lambda}\left(\mathbf{z}_{i}-\mathbf{z}\right)\right) \boldsymbol{\beta} \mathbf{q}_{t}+\boldsymbol{\delta} \mathbf{x}_{i t}+u_{i t} .
$$

We can use a set of time dummies (one per time period) to estimate, $\boldsymbol{\beta} \mathbf{q}_{t}$, the common effect of the common events in (3). The institution-specific effect of common events $\mathbf{q}_{t}$ is proportional to the term $\boldsymbol{\lambda}\left(\mathbf{z}_{i}-\mathbf{z}\right)$ on the right-hand side, where $\mathbf{z}$ is the cross-country average of $\mathbf{z}_{i}$. The form of (3) tells us to estimate the crucial parameter $\boldsymbol{\lambda}$ by NLS and include fixed effects to pick up the countryspecific intercept given by the first term. We use both annual data and five-year averages. The latter may be more robust to measurement error and allow better for discretionary adjustments of policy than yearly data.

Observable economic events Yet another way of testing whether institutions induce different policy responses to shocks and other variables is to focus on specific observable events. These may be economic events, such as changes in the price of oil, country income, or changes in population structure. To assess whether the impact of such common or country-specific events on policy outcomes depends on institutions, we can re-write (1) as:

$$
y_{i t}=\left(\alpha_{i}+\boldsymbol{\eta} \mathbf{z}_{i}\right)+\left(\boldsymbol{\beta}+\boldsymbol{\lambda} \mathbf{z}_{i}\right) \mathbf{q}_{t}+\left(\boldsymbol{\gamma}+\boldsymbol{\mu} \mathbf{z}_{i}\right) \mathbf{s}_{i t}+\boldsymbol{\delta} \mathbf{x}_{i t}+u_{i t} .
$$

Finding coefficients $\boldsymbol{\mu}$ or $\boldsymbol{\lambda}$ different from zero thus implies an indirect effect of institutions through these observable events. We use two basic estimation methods: (i) fixed effects estimation, to control for the first country-specific term on the right-hand side of (4); sometimes we jointly estimate spending, revenues and 
deficit equation by seemingly unrelated regressions; (ii) we take first differences to wipe this term out and then estimate by instrumental variables. In (i ) and (ii) we always include the lagged dependent variable $y_{i t-1}$ either in $\mathbf{x}_{i t}$ or in $\mathbf{s}_{i t} .{ }^{6}$ We also report some GLS estimates of the difference specification (with no lagged dependent variable), to allow for heteroskedasticity and panel-specific autocorrelation in $u_{i t}$.

Electoral cycles Finally, we test for an institution-dependent response to observable political events, in the form of elections. As we saw in Section 2, theory indicates that we should expect at least the electoral rule to affect the strength of the electoral cycle. For this purpose, we construct an indicator variable, $E L_{t}$, taking a value of 1 if there was an election in country $i$ in year $t$, and 0 otherwise (sometimes, as noted below, $E L_{t}$ equals 1 if there was an election in either year $t$ or year $t+1)$. For presidential regimes, the election date is that of the president, for parliamentary regimes it is that of the legislative assembly's lower house. We then expand $\mathbf{s}_{i t}$, the vector of country-specific events, to include indicator variables for election years, $E L_{t}$, and post-election years, $E L_{t-1}$. Otherwise, the specification is identical to that in our tests for institution-dependent responses to economic events. The estimation methods are also the same as those described above, except that the specification includes a set of common time dummies, to allow a more precise estimation of the electoral cycle.

\section{Results}

In this section, we report the results obtained by applying the methodology discussed in the previous section to our three policy outcomes: the size of government, the government surplus and the composition of government spending.

\footnotetext{
${ }^{6}$ As is well known, the presence of a lagged dependent variable can bias the fixed-effects estimator even if the error term is not correlated over time. But in panels where the time series dimension is as long as ours, the bias is rather small. Transforming the data to first differences removes the fixed effect part of the error term, but may aggravate the correlation between the error term and the lagged dependent variable (see, for instance Baltagi, 1995, Ch 8). This is why when differencing we rely on instrumental variable estimation, where the instruments are the lagged explanatory variables (in differences) and the lagged dependent variable in level lagged twice, as suggested by Anderson and Hsiao (1981) and Arrellano and Bond (1991).
} 


\subsection{Size and surplus of government}

Cross-country variation in the size of government We begin with the cross-sectional regressions testing $H_{0}^{D}$ for the presence of a direct effect of institutions on the size of government. The results are displayed in Table 4. The major dependent variable is expenditures by central government (Columns 1-3 and 7), but we also include results for central government revenue (Columns 4-5) and general government expenditure (Column 6). Every specification includes our basic set of controls $X_{1}$ and all but one also include dummies for continents and colonial origin. Every regression except the last one relies on data from the full length of the panel. Most regressions refer to our Default sample of countries (a Gastil index less than or equal to 3.5, applied year by year), but two (Columns 3 and 5) refer to the Broad sample. All variables are measured in levels. The estimation method is Weighted Least Squares, where each country's weight is proportional to the length of its panel (the results for unweighted OLS regressions are similar). The table displays the estimated $\eta$ parameters for the PRES and MAJ dummies. Bracketed expressions are $p$-values for false rejection of $\eta=0$. Boldface font denotes a coefficient significantly different from zero at the $10 \%$ level.

Our two institutional measures always enter with a negative sign. The effect for $M A J$ is statistically insignificant in half the cases. The finding that majoritarian countries have significantly smaller governments in terms of revenue but not in terms of spending turns out to reflect systematically smaller deficits. 7 Evidence of a large and statistically robust negative effect of majoritarian elections is limited to general government expenditures. Note, however, that - due to data availability - the panel in this case is both shorter and restricted to a much smaller number of countries. Our result that majoritarian countries have smaller general governments is consistent with the findings by Milesi-Ferretti et al. (2000) for the OECD countries.

The presidential dummy variable is instead consistently significant, except in the case of general government where the sample includes considerably fewer presidential regimes, and in the broad sample that includes the more dubious democracies. The finding that presidential regimes have smaller governments is clearly in line with the theoretical prediction in Section 2. According to the point

\footnotetext{
${ }^{7}$ Similar cross-sectional estimates for the government surplus indicate that average deficits are smaller in countries with either presidential regimes or majoritarian elections. The effect of the electoral system is considerably more robust to inclusion of regional and colonial dummies, however. Consistent with our findings on spending and revenue in Table 4, the estimates imply a smaller average deficit by 1.5 to 2 percent of GDP under plurality rule.
} 
estimates, the effect is substantial: about 5 percent of GDP. It appears to be slightly smaller in the larger sample, which corresponds to the broader definition of democracy.

In some specifications, not reported, we also included a dummy variable taking a value of 1 for federal countries, and 0 otherwise. The coefficients of interest, of PRES and MAJ, were never affected. The federalism variable had a negative estimated coefficient that was statistically significant in some regressions but not in others. ${ }^{8}$

As the last column shows, the negative effect of PRES is much stronger - above 10 percent of GDP - for cross sections based on data from the 1990s, rather than the whole sample. It is also statistically much more robust. These findings are consistent with the empirical results in Persson and Tabellini (1999), who considered data from around 1990. Together, the findings suggest that the negative sign of the PRES dummy might largely reflect a faster growth of government in parliamentary regimes in the last four decades. As Figure 3 illustrates, this time pattern is clearly visible already in the raw data. The graph is identical to Figure 2, except that the data is partitioned into presidential regimes, marked with black diamonds and a thick curve for the average, and parliamentary regimes, marked with circles and a thin curve. ${ }^{9}$

Unobservable common events and the size of government Next, we turn to the time variation in the data, testing $H_{0}^{I}$ for (the absence of) an institutiondependent reaction of the size of government to economic and political events. We begin with the effect of unobservable common events variables, using the specification in equation (3).

Table 5 displays selected results for expenditures and revenue as the dependent variable, for yearly data and five-year averages, and for the broad and default sample of countries. All variables are measured in levels and each specification

\footnotetext{
${ }^{8}$ We relied on threee very closely related classifications of countries into federal or unitary states, provided by Boix (2000), Scartascini and Crain (2000) and Treisman (2000), that mainly look at the political structure and the authonomy of states and local governments. Scartsascini and Crain (2000) find a robust and significant effect of federalism on the size of government in a similar sample of countries. These measures of federalism, like the centralization of spending discussed in the previous section, are uncorrelated with both MAJ and PRES.

${ }^{9}$ The result that the estimated coefficient on PRES is larger in absolute value in the more recent cross sectional estimates is not due to a different sample of countries beeing included in later years compared to the early period, since it holds even if we hold the sample of countries fixed.
} 
includes country fixed effects on top of the basic controls in $X_{1}$. The first two rows in the table report the coefficients on the institutional variables: our estimates of $\boldsymbol{\lambda}$ in (3). The results remain similar if we extend the vector of observable controls to include the lagged dependent variable or income shocks, as in Table 6 below. Both PRES and MAJ are negative and highly significant across all specifications.

One way of interpreting the results is to consider a common event in some period $t$ that raises government spending by 1 percent of GDP in an average country: i.e., an event corresponding to $\boldsymbol{\beta}\left(\mathbf{q}_{t}-\mathbf{q}_{t-1}\right)=1$. Then, a coefficient of about -1 on PRES means that the effect is about 1.4 percent of GDP in parliamentary regimes, but only 0.4 percent in presidential regimes (recall that $z_{i}$ in (3) is adjusted by the sample mean, which is about 0.4 for PRES). Similarly, the effect is $\frac{1}{3}$ of a percent smaller under majoritarian rather than proportional elections. Identical specifications for the government surplus (not shown) produce similar results. 10

The estimated effects of the common events on the size of government, the sequence of $\boldsymbol{\beta} \mathbf{q}_{t}$ in (3), generally reflect the time pattern suggested by Figures 2 and 3: the estimated coefficients on the time dummies grow from the beginning of the sample until the mid 1980s, then they remain constant or drop slightly. Their sign depend on the precise specification (since we include fixed effects, data are measured in deviations from country means), but their time profile is stable. Figure 4 illustrates the estimated coefficients of the time dummies pertaining to column 1 in Table 5. The effects of the common events are shown by the dashed line for an average country, by the thick solid line for a presidential regime $(P R E S=1)$, and by a thin solid line for a parliamentary regime $(P R E S=0)$. The negative parameter estimates reported in Table 5 thus suggest that whatever unobservable events caused the growth in government in the sample as a whole, their effect was significantly smaller in countries with presidential regimes and majoritarian elections.

Another way of gauging the results is thus to consider the cumulative effect of the common events over the course of the sample, as measured by $\boldsymbol{\beta}\left(\mathbf{q}_{T}-\mathbf{q}_{1}\right)$ - in terms of Figure 4 this measure corresponds to the vertical distance between the first and the last observation. The cumulative effect is positive on average

\footnotetext{
${ }^{10} \mathrm{NLS}$ estimation of the adjustment of the government surplus suggest that unobservable common events have smaller effects in presidential regimes and under majoritarian elections. An unobservable event that raises the average country's surplus by 1 percent of GDP thus has an effect about 0.5 percent smaller both in presidential (vs. parliamentary) regimes and under majoritarian (vs. proportional) elections.
} 
(i.e., for the sample as a whole). The last two rows in Table 5 show how much this cumulative effect differs across institutions, according to our point estimates. For government spending, the difference between presidential and parliamentary regimes is just above 10 percent of GDP, which well matches our estimate in the last column of Table 4 of a cross-sectional difference in the 1990s of just above 10 percent. The influence of the electoral rule is also statistically significant but quantitatively less important, between 3 and 6 percentage points of GDP, again about the same order of magnitude as in the cross-sectional regressions.

Altogether, the results in Tables 4 and 5 convey a similar message. The size of government is strongly influenced by the political constitution. Proportional and parliamentary systems spend the most, while presidential regimes and countries electing their legislatures by plurality rules spend the least. The regime type has a larger and more robust effect than the electoral rule.

Observable economic events and the size of government We now ask whether the impact of observable determinants of the size of government depends on institutions. We mainly focus on income shocks, since they are one of the main sources of time variation in government outlays and receipts. Our goal is to find out whether the cyclical response of fiscal policy is affected by the political constitution. We measure income shocks (YSHOCK) as the log-deviation of real income from its (Hodrick-Prescott) trend. We then interact this variable with our two measures of institutions, so as to estimate the coefficients $\boldsymbol{\mu}$ and $\boldsymbol{\lambda}$ in equation (4). As institutions might also influence the persistence of spending or taxation after an income shock, we also interact the lagged dependent variable with PRES and MAJ. Throughout, we treat income shocks as exogenous in the regression. Their amplitude is about the same on average in countries ruled by different institutions.

There are several reasons to expect that the cyclical response of fiscal policy might be influenced by the constitution. First, cyclical fluctuations induce an automatic response of entitlement spending: welfare spending as a fraction of GDP is likely to increase more than other government outlays during cyclical downturns. But the constitution is likely to influence the relative importance of entitlement spending. According to the theories reviewed in section 2, proportional and parliamentary systems should have bigger welfare states. This prior is also born out in the data: as further discussed below, parliamentary countries with proportional elections devote almost 12 percent of GDP on average (across countries and years) to social security and welfare spending. In the remaining 
groups (presidential or parliamentary-majoritarian), this average is about $4-5 \%$ of GDP. Hence, we should expect spending to be more counter-cyclical and more elastic to cyclical fluctuations in proportional-parliamentary systems .

Second, the constitution might also have a direct effect on the discretionary reaction of policy to exogenous events. Coalition governments are often said to have a greater status quo bias than single party majorities, because of the difficulties of bargaining within the governing coalitions. The number of veto players is generally thought to be higher in presidential regimes, because of their stronger separation of powers. More generally, the different rules for legislative bargaining in presidential and parliamentary democracies suggest that shocks to the status quo might induce different policy reactions in these regimes. Here, however, it is more difficult to predict the observed response of government spending or revenue to aggregate income shocks.

Yet another possibility is that some types of democracies are more likely to face borrowing constraints in financial markets. As already noted, many presidential regimes are in Latin America, where sovereign debt crisis or exchange rate crisis have been more frequent than in other democracies. Borrowing constraints would impart a procyclical bias to fiscal policy: governments are forced to cut spending or raise revenues when hit by a recession or by a financial crisis, since they cannot let the deficit absorb the shock. Indeed, other studies have shown that fiscal policy in Latin America tends to be much more pro-cyclical than elsewhere - see in particular Gavin and Perotti (1997).

Table 6 displays our estimates, for government spending and revenues (of central government only). We rely on the three estimation methods discussed in Section 4, namely in levels with country fixed effects, and in differences with instrumental variables and with GLS. When estimating in levels, the spending and revenues equation are often jointly estimated by SUR as indicated. The vector of other controls $X_{2}$, not reported in the table, includes the same basic variable as in the previous tables, plus the oil price and the trend of aggregate real income from which the shock is computed. Time-dummy variables, colonial origin and continental dummy variables are not included in the regression. A $P^{*}$ in front of a variable denotes that the variable is interacted with the PRES dummy variable, while a $M^{*}$ denotes interaction with the $M A J$ dummy. The results we report here are robust to estimation methods, samples and measurements (we also measured income shocks as the yearly growth rate in income, and obtained similar findings). We also tried to interact institutions with other common and country-specific socio-economic variables, such as the oil price or the proportion 
of population above 65 years of age. Some of these interaction terms were occasionally significantly different from zero; although not robust to specification or estimation method, these results reinforce the general message below.

The central message of Table 6 is that institutions matter a great deal. Consider the first three columns of the table. In proportional and parliamentary countries, income shocks affect central government spending as a proportion of GDP. The estimated coefficient of $Y S H O C K$ is consistently negative with a value around -0.2 , meaning that a $10 \%$ drop in real income induces a rise in the spending ratio of 2 percentage points. When the size of government is measured by revenues, rather than by spending, the estimated coefficient drops in absolute value, but remains negative and statically significant. Because spending and revenue are highly serially correlated, this effect persists over time. By contrast, policy in presidential and majoritarian countries is not affected by the income shock; in presidential countries spending even appears to be pro-cyclical. Moreover, persistence in the size of government is significantly smaller, particularly in presidential regimes. This pattern of reactions to income shocks is consistent with the observation that welfare state tends to be larger in proportional cum parliamentary systems: the outlays of such entitlement programs are fixed in cash terms, or perhaps even inversely related to income. But, as argued above, there are other plausible reasons why government outlays might move more than in proportion to aggregate income in proportional-parliamentary democracies but not elsewhere.

To gain a better understanding, column 4 disaggregates income shocks into positive $\left(Y S H_{-} P O S\right)$ and negative $\left(Y S H_{-} N E G\right)$. An asymmetry is apparent. Only negative income shocks have a statistically significant effect on the spending ratio, and their estimated coefficient is much larger in absolute value. This asymmetric effect suggests that a ratchet effect might be in place. A negative income shock induces a lasting expansion in the size of government, which is not undone when income grows above potential. But this effect is not present in presidential or majoritarian countries, where a ratchet effect instead appears to be associated with positive income shocks. This different ratchet effect across constitutional types is hard to explain just on the basis of the different size of entitlement programs. It is instead in line with the idea that presidential countries are more likely to face borrowing constraints: when positive income shock occurs, they are able to expand aggregate spending more than in proportion to income; but when hit by a recession, they are forced to enact sharp spending cuts. If correct, this interpretation would lead to the further question of why presidential regimes would be more likely to be credit rationed, or more generally why they would be more 
risky borrowers. Whatever the interpretation of this ratchet effect, it could contribute to account for the differential growth of government in different political systems that we uncovered in the previous subsections. Thus, the possibility and precise explanation of an institution-dependent ratchet effects certainly deserve more attention in future research.

Finally, in columns 5 and 6 we turn to other estimation methods. The results on the income shocks stand, but the coefficient on lagged spending drops and differences across institutions disappear. This last finding is important, as this coefficient could be biased in the level-specification due to the panel structure of the data. Note also that these results are robust across samples of countries. In particular, the same pattern of reactions to income shocks are observed in our broad and narrow samples of democracies. ${ }^{11}$

Observable economic events and the budget surplus As the budget surplus is defined as the difference between revenues and spending, it is natural to ask how the same observable events manifest themselves in the budget surplus. To do that, we use a specification consistent with the earlier regressions for central government revenues and spending. As those include lagged revenues and spending, respectively, we include the same variables in the surplus regression (but do not constrain their respective coefficients to sum to zero). Since the surplus is also closely related to changes in government debt, stationarity of the debt to GDP ratio requires that the surplus also reacts to the outstanding stock of debt. We thus include lagged debt in the regression (including it in the spending and revenues regressions above does not change the previous results). We allow the coefficients on lagged debt, as well as on lagged spending and revenues, to differ for countries ruled by different institutions, but for the rest, the specification is the same as in Table 6 .

As in the previous subsections, we estimate the regressions in levels and in

\footnotetext{
${ }^{11}$ We have assumed that the coefficients on $L A G \_S I Z E$ and $Y S H O C K$ are the same within country groups, but different across groups with different political institutions. A more general approach would be to allow coefficients to differ across all countries, while looking for differences across countries belonging to different groups. We have also tried the latter approach, by estimating the regressions in Table 6 by the method of random coeffcients. The (mean) coefficients on $L A G_{-} S I Z E$ in the group of presidential regimes is about 0.2 higher than in the group of parliamentary regimes in consistency with the pooled regressions (both coefficients are precisely estimated, although lower than in the pooled regressions). Similarly, the estimated coefficient on $Y S H O C K$ is negative in the parliamentary group, wheras it is positive in the presidential group (although both have a high standard error).
} 
differences. In the first case, we always include country fixed effects and estimate by SUR, jointly with the spending and revenues regressions (the results are similar if we estimate the surplus regression in isolation). When estimating in differences, we rely on IV estimation, as in the previous subsection. But here, we exploit the fact that the surplus is approximately equal to the change in debt (with reverse sign). We thus run a regression of the surplus (in levels) on the lagged surplus and on all the other right hand side variables in first differences, omitting lagged debt. The instruments are the levels of spending, revenues and surplus, all lagged twice, as well as the other right hand side variables in differences lagged once. ${ }^{12}$

Table 7 shows the results. Consider the first three columns, estimated in levels. As expected, we find that surpluses (as a \% of GDP) are procyclical - they go up with positive income shocks - in the average country. But presidential regimes are different, with acyclical or even countercyclical surpluses. Majoritarian elections seem to have a similar effect, albeit not statistically significant. The order of magnitude of these estimated coefficients is in line with those estimated in Table 6 with regard to revenues and spending. These results are also stable across the samples of democracies, except that the presidential effect becomes even stronger in the narrow sample. The fourth column disaggregates the income shocks into positive and negative shocks. As in the case of spending, there is some evidence of a ratchet effect: negative income shocks reduce the surplus while positive shocks have no effect. But now the differences across institutions are not statistically significant.

The first three rows of the table show the reaction of the surplus to lagged debt. As expected, the surplus is higher when the debt is larger. But this does not happen in the presidential regimes (except in the narrow sample, where all regimes appear similar). Though not reported in the Table, we also find that the surplus reacts to lagged spending and revenues. As already found in Table 6, the coefficients on lagged spending and revenues is smaller (in absolute value) in the

${ }^{12}$ Write the level specification for the surplus as:

$$
z_{i t}=\alpha_{i}+\gamma_{i} \tau_{i t-1}-\beta_{i} g_{i t-1}+\lambda_{i} b_{i t-1}+\delta \mathbf{x}_{i t}+u_{i t}
$$

where $z$ denotes the surplus, $\tau$ revenue, $g$ spending and $b$ public debt, all in percentage of GDP, while $\mathbf{x}$ denotes the vector of observable shocks. Taking differences $(\Delta)$ and noting that $z_{i t-1} \approx-\Delta b_{i t-1}$, we can rewrite the surplus regression as:

$$
z_{i t}=\gamma_{i} \Delta \tau_{i t-1}-\beta_{i} \Delta g_{i t-1}+\left(1-\lambda_{i}\right) z_{i t-1}+\boldsymbol{\delta} \boldsymbol{\Delta} \mathbf{x}_{i t}+\Delta u_{i t} .
$$


PRES countries. Thus, the regime type appears to influence not only the reaction of the surplus to income shocks, but also its dynamics.

Finally, the last two columns of Table 7 report the IV estimates of the specification in differences. This estimation method leads to very unstable estimates, except for the estimated coefficient on lagged deficit which has most of the explanatory power (the estimated coefficient on lagged deficit is much larger than that on lagged debt, as it ought to be, because of the variable transformation - see the expressions in Footnote 10). Deficits in presidential regimes appear to have much less inertia (more mean reversion) than in parliamentary regimes. Majoritarian elections modify the dynamics in a similar way, but, again, not as strongly. These results are consistent with the different dynamic response of deficits to debt in the levels regressions. Although evidence remains of a different reaction to income shocks in presidential regimes, the coefficient for the reference countries is almost zero. Moreover, the estimated coefficients on the income shocks are now quite unstable across specification and lists of instruments, a sign that these IV estimates are less reliable.

Electoral cycles We next ask whether there is an electoral cycle in spending or revenue, whether it occurs before or after the elections, and whether its magnitude depends on institutions. As explained in Section 4, we essentially rely on the same specification as that underlying Table 6 , except that we expand $\mathbf{s}_{i t}$ with indicator variables for current and lagged elections. We also drop the price of oil from the specification, and include instead a set of year dummies, so as to identify the effect of elections more precisely. $P R E S$ and $M A J$ are still interacted with the lagged dependent variable and with $Y S H O C K$, as in Table 6 . In the levels specifications, we estimate the spending and revenues equations jointly by SUR.

Table 8 reports the results for different samples and different estimation methods. The first six columns rely on the basic specification where $E L_{t}$ includes only the election year. As this measure does not distinguish between elections held early and late in the year, we have also used an alternative measure where $E L_{t}$ is redefined as taking a value of 1 if there was an election in either year $t$ or in year $t+1$. That is, a pre-election cycle is defined by fiscal policy in the year before the election as well as in the year of the election. Our estimates in the last two columns of the table rely on this alternative definition.

We find a strong electoral cycle in spending and taxation, but it takes a very different form in presidential and parliamentary democracies. ${ }^{13}$ Consider presiden-

\footnotetext{
${ }^{13}$ Earlier studies on international data conducted with different methodologies had typically
} 
tial regimes first. There is strong evidence that they postpone fiscal adjustments until after the election. Once the election is over, spending is cut by almost 1 percent of GDP and revenues hiked by at least 0.5 percent of GDP. Whether presidential regimes have a pre-election cycle is more ambiguous and sensitive to our definition of the election dummy. According to columns 1-6, nothing of statistical significance happens during the election year. But estimates based on the more comprehensive definition of $E L_{t}$ in the last two columns suggest a tax break of about $0.7 \%$ of GDP before the election.

In parliamentary regimes, on the other hand, we only find a pre-election cycle, and only on the revenue side. Revenues are cut by about $0.3 \%$ before elections, while government spending does not seem affected by the election date.

We also investigated the specific prediction of the theory in Section 2, that majoritarian electoral rules are associated with stronger electoral cycles (results not reported). While the coefficient on $E L_{t}$ typically turns out to be larger (in absolute value) in parliamentary countries with plurality elections than in those with proportional elections, the difference is only statistically significant in a few specifications.

Finally, we look for evidence of electoral cycles in the budget surplus. As Table 9 shows, we find a post-election cycle: improvements in the surplus on the order of $0.5-1 \%$ points of GDP are postponed until the year after the election. Again, this electoral cycle is present only in presidential regimes, consistently with our results for government spending and revenue. This cycle is statistically significant only in the estimation in differences, however, and appears more pronounced in the broad sample of democracies. There is no evidence of a pre-election deficit cycle in parliamentary regimes. Neither is there any systematic influence of the electoral rule in these regimes (results not shown in the Table). As a final check on the robustness we also used the more comprehensive definition of the pre-election cycle. The results (not reported) do not change much, except that the evidence of a post-election cycle in the budget surplus for presidential regimes becomes even stronger.

To understand why presidential regimes display systematic cycles in all fiscal aggregates before and after elections, while parliamentary regimes mainly

not found robust evidence of an electoral cycle (see Alesina, Roubini and Cohen, 1997 for a summary). An exception is the recent study by Shi and Svensson (2000), who use panel data for over 100 countries and find significant electoral cycles in spending, revenues and government deficits. But they only search for pre-election cycles and do not explore institutional differences across countries. 
have a pre-election revenue cycle, is an interesting issue for further theoretical research. Future research ought to pay more attention to one issue in particular. While in presidential regimes elections of the president tend to be exogenous, in many parliamentary regimes they are endogenous; in our sample, elections are also somewhat more frequent in parliamentary than in presidential regimes. In our estimates we ignore this potentially important difference across groups of countries.

\subsection{Composition of spending}

We now turn to the composition of government. Recall that our two measures of composition include central government spending on social security and welfare, either as a percent of GDP $(S S W / G D P)$, or as a ratio to central government spending on goods and services $(S S W / G D S)$. We have already noted that different groups of countries have very different welfare states: the large welfare states are a feature of proportional cum parliamentary systems. But do these differences remain after controlling for other social and economic features of these countries? And does social security and welfare spending react to income shocks and to election dates? As the methodological considerations closely follow those in the previous subsection, we keep the discussion of our results more brief.

Cross-section regressions We start with cross-sectional tests for a direct effect of institutions. Estimation results are shown in Table 10 for both our measures of composition. Note that data availability restricts the full sample to the period from 1972. The results indicate that broad, non-targeted programs are indeed systematically smaller under majoritarian elections, as predicted by the theory discussed in Section 2. Ceteris paribus, social security and welfare spending is smaller by 1-2 percentage points, when measured as a percentage of GDP, and about $0.20-0.40$ points lower, when measured as a ratio to spending on goods and services (in this latter case, the dependent variable takes values close to 1 on average). Statistically, these results are more fragile to the sample and the inclusion of socio-economic controls than were the results for overall spending. Qualitatively, they are in line with the findings of Milesi-Ferretti et al (2000) for the OECD countries.

Unlike for the size of government, however, we find no discernible effect of the regime type on our measures of composition after controlling for our usual observable variables. On average, presidential regimes have much smaller welfare 
states than parliamentary countries. But this appears to be due to a different demographic composition and to other economic features, not to the political institution per se, at least when we neglect the time variation in the data.

Unobservable common events What about the indirect effects of institutions? Results from our estimates of the adjustment to common unobservable events are collected in Table 11. As in the case of overall spending, we find a strong and significant influence of political institutions. Now both the electoral rule and the regime type matter. Unobservable common events have a smaller effect on the spending ratio $(S S W / G D S)$ under majoritarian elections and under presidential regimes. When social security and welfare is measured as a share of GDP, the estimated effect of presidential regimes is particularly relevant, with a cumulative difference of about 5 percent of GDP. As the estimated effects of the common events (the time sequence of $\boldsymbol{\beta} \mathbf{q}_{t}$ ) grow throughout the entire course of the sample, the last result can be interpreted as evidence of more rapid growth of welfare-state spending in parliamentary than in presidential regimes. Finally, note that the influence of political institutions appears weaker in the broader sample of democracies. A likely reason is that this broad sample includes a number of developing countries, where the welfare state is too small to be meaningfully compared to the larger welfare states in the OECD.

Observable economic events Table 12 summarizes our results regarding the adjustment to income shocks. Here we only report results on social security and welfare as a share of GDP, as the results for $S S W / G D S$ are less robust. The estimated coefficients resemble the pattern we obtained in Table 6 for the overall size of government. Presidential and majoritarian systems have a dampened reaction to income shocks, and less persistence, compared to parliamentary and proportional systems. The result on persistence is less robust across estimation methods, however, as already found in Table 6. Moreover, comparing these estimates with those in Table 6, income shocks have a smaller impact on this component of the budget than on the overall budget size. This suggests that automatic stabilizers due to the larger welfare states of proportional-parliamentary countries cannot fully explain the different cyclical reaction of the size of government and the budget surplus, noted in the previous subsection.

Electoral cycles Do we find a systematic effect of elections on the composition of spending? The answer is positive, but with some important differences relative 
to our findings on the overall size of government. ${ }^{14}$ As Table 13 shows, the postelection cycle in presidential regimes can be detected in only some specifications and estimation methods. On the other hand, parliamentary regimes now display a statistically significant pre-election cycle in this component of spending (about 0.2 percent of GDP), which continues in the post-election year. But this hike in social security spending is present only under proportional elections. Although the estimates are not entirely stable across samples and estimation methods, our results suggest quite a subtle pattern. In presidential regimes, spending on social security falls after the elections, as painful adjustments seem to be delayed. In parliamentary regimes, on the other hand, program expansions seem to take place during election years, although only in countries with proportional elections. In proportional parliamentary regimes favors granted during the electoral campaign are sustained after the elections.

We find these results intriguing: without taking explicit account of electoral rules and political regimes, we would not have discovered these systematic patterns in the data. A greater reliance on social-security spending around election time in parliamentary and proportional systems is perhaps plausible if - as in the theory discussed in Section 2 - politicians indeed have greater overall incentives to use broad programs for seeking electoral support in those systems. But it remains to work out the details - and auxiliary predictions - of such a theory.

\section{Conclusion}

Do political institutions shape economic policy? Our empirical results, summarized in Table 14, strongly suggest that the answer is yes. Several of these empirical regularities are in line with the first wave of theory discussed in Section 2. In particular, as predicted, presidential regimes have smaller governments, while majoritarian elections lead to smaller welfare programs.

But other findings still await a satisfactory theoretical explanation. A puzzling but robust feature of the data is that the cyclical response of aggregate spending and budget deficits is much smaller in presidential regimes and under majoritarian elections, compared to proportional-parliamentary systems. Larger welfare programs in proportional-parliamentary systems inducing a larger automatic reaction of government outlays to cyclical fluctuations could partly account for this finding. But this is unlikely to be the whole story. In particular, different political

\footnotetext{
${ }^{14}$ When estimating by SUR, the SSW/GDP equation is jointly estimated with the corresponding equation on the size of government. .
} 
constitutions seem to be associated with different ratchet effects in government spending.

Another puzzling but robust finding concerns electoral cycles. Fiscal adjustment is delayed until after the election, but only in presidential regimes. And social transfers tend to grow around the election date, but only in proportional cum parliamentary systems. Why do we observe these different patterns in countries ruled by different institutions?

These are promising first steps in a research program, but much work remains to be done. One direction is to refine the theory of policy. To understand the cyclical reaction of fiscal policy, or why fiscal adjustments are delayed, we need dynamic models. This theory does not yet exist, as the existing predictions of comparative politics and economic policy are generally drawn from static models, in which there is no role for state variables such as government debt, or no link between current policy decisions and the future status quo.

On the policy side, we have concentrated on government spending. It would be interesting, and certainly feasible, to study other policy instruments — such as the structure of taxation, including trade policy — with similar methods. On the institutional side, one should study the effect on policy of more detailed constitutional features; for instance, different types of checks and balances, or different types of confidence requirements.

This suggests another direction of research, namely refined measurement of political institutions. In some cases, such measurement will involve a mere, but time-consuming, compilation of data from existing sources. One example would be to collect panel data for continuous measures of the two aspects of the electoral rule discussed in Section 2: district size and the electoral formula. In other cases, better measures will require the collection of new primary data. An example would be to try and find continuous or multidimensional measures of checks and balances in different political regimes. ${ }^{15}$ As this may be a labor-intensive and open-ended task, it is important to use theory as a guide.

Some econometric issues certainly need to be explored in more detail. Even with refined measurement, considerable measurement error will remain in our data. Sharper theory would help trade off the prospective biases due to measurement and specification errors. Sharper hypotheses, derived from dynamic models, would also help avoid the pitfalls of estimation in dynamic panels.

All in all, a close interplay of theory, measurement and statistical work appears

\footnotetext{
${ }^{15}$ Attempts to construct such measures have been made by Beck et al (1999) and Shugart and Carey (1992).
} 
essential for making progress on the broad questions dealt with in this paper. The empirical findings described in this paper suggest that it is worth trying. 


\section{References}

[1] Alesina, A., and Drazen, A. (1991), "Why are Stabilizations Delayed?." American Economic Review 81, 1170-1188.

[2] Alesina, A., N. Roubini and G. Cohen (1997), Political Cycles and the Macroeconomy, MIT Press.

[3] Alesina, A., and Tabellini, G. (1990), "A Positive Theory of Fiscal Deficits and Government Debt." Review of Economic Studies 57, 403-414.

[4] Austen-Smith, D. (2000), "Redistributing Income under Proportional Representation", Journal of Political Economy, Decemeber, Vol. 108 n. 6, 12351269

[5] Anderson, T and C. Hsiao (1981), "Estimation of Dynamic Models with Error Components", Journal of the American Statistical Association 76, 598-606.

[6] Arellano, M. and S. Bond (1991), "Some Tests of Specification for Panel Data: Monte Carlo Evidence and an Application to Employment Equations", Review of Economic Studies 58, 277-297.

[7] Baltagi, B. (1995), Econometric Analysis of Panel Data, Wiley.

[8] Barro, R. (1998), "Determinants of Democracy".

[9] Beck, T., G. Clarke, A. Groff, and P. Keefer (2000), "New Tools and Tests in Comparative Politcal Economy: The Database of Political Institutions" mimeo, The World Bank.

[10] Boix, C. (2000), "Democracy, development and the public sector", mimeo, University of Chicago

[11] Blais, A. and L. Massicotte (1996), "Electoral Systems" in LeDuc, L., R. Niemei and P. Norris (eds.) Comparing Democracies: Elections and Voting in Global Perspective, Sage.

[12] Blanchard, O. and J.Wolfers (2000), "The Role of Shocks and Institutions in the Rise of European Unemployment: The Aggregate Evidence, 1999 Harry Johnson Lecture", Economic Journal 100, C1-33. 
[13] Bohn, H. and R. Inman (1996), "Balanced Budget Rules and Public Deficits: Evidence from US States", Carnegie-Rochester Series on Public Policy 45, 13-76.

[14] Castels, F. (1998), Comparative Public Policy. Patterns of Post-war Transformation, Edward Elgar.

[15] Cox, G. (1997), Making Votes Count, Cambridge University Press.

[16] Diermeier, D. and T. Feddersen (1998), "Cohesion in Legislatures and the Vote of Confidence Procedure", American Political Science Review 92, 611621.

[17] Feld, L. and J. Matsusaka (2000), "Budget Referendums and Government Spending: Evidence from Swiss Cantons", CES_Ifo working paper n. 323.

[18] Gavin, M. and R. Perotti (1997), "Fiscal Policy in Latin America", in Bernanke, B. and J. Rotemberg (eds.), NBER Macroeconomics Annual 1997, MIT Press.

[19] Grilli, V., Masciandaro, D., and Tabellini, G. (1991), "Political and Monetary Institutions and Public Financial Policies in the Industrial Countries." Economic Policy 13, 342-392.

[20] Hallerberg, M. and J. Von Hagen (1999), "Electoral Institutions, Cabinet Negotiations, and Budge Deficits in the European Union", in J. Poterba and J. Von Hagen (eds.), Fiscal Institutions and Fiscal Performance, University of Chicago Press.

[21] Holmström, B. (1982), "Managerial Incentive Problems - A Dynamic Perspective", in Essays in Economics and Management in Honor of Lars Wahlbeck, Helsinki, Swedish School of Economics.

[22] Lijphart, A. (1994), Electoral Systems and Party Systems. A Study of Twenty-Seven Democracies 1945-1990, Oxford University Press.

[23] Lijphart, A (1999), Patterns of Democracy: Government Forms and Performance in Thirty-Six Countries, Yale University Press.

[24] Lizzeri, A. and N. Persico (2000), "The Provision of Public Goods under Alternative Electoral Incentives", American Economic Review, forthcoming. 
[25] Kontopoulos, Y., and Perotti, R. (1999), "Government Fragmentation and Fiscal Policy Outcomes: Evidence from the OECD countries," in Poterba, J. and von Hagen, J (eds.) Fiscal Institutions and Fiscal Preference, University of Chicago Press.

[26] Milesi-Ferretti G-M., Perotti, R. and M. Rostagno (2000), "Electoral Systems and the Composition of Public Spending", mimeo, Columbia University.

[27] Persson, T., Roland, G., and G. Tabellini (1997), "Separation of Powers and Political Accountability", Quarterly Journal of Economics 112, 310-27.

[28] Persson, T., Roland, G., and G. Tabellini (2000), "Comparative Politics and Public Finance", Journal of Political Economy 108, 1121-1141.

[29] Persson, T. and G. Tabellini (1999), "The Size and Scope of Government: Comparative Politics with Rational Politicians, 1998 Alfred Marshall Lecture", European Economic Review 43, 699-735.

[30] Persson, T. and G. Tabellini (2000), Political Economics: Explaining Economic Policy, MIT Press.

[31] Persson, T., Tabellini, G., and F. Trebbi (2000), "Electoral Rules and Corruption", mimeo, Institute for International Economic Studies.

[32] Pommerhene, W. (1990), "The Empirical Relevance of Comparative Institutional Analysis", European Economic Review 34, 458-69.

[33] Poterba, J. and J. von Hagen (1999), Fiscal Institutions and Fiscal Performance, University of Chicago Press.

[34] Roubini, N., and Sachs, J. (1989), "Political and Economic Determinants of Budget Deficits in the Industrial Democracies." European Economic Review 33, 903-933.

[35] Scartascini, C. and M. Crain (2001), "The Size and Composition of Government Spending in Multi-Party Systems", mimeo, George Mason University

[36] Shi, M. and J. Svensson (2000), "Conditional Political Business Cycles: Theory and Evidence", mimeo, Institute for International Economic Studies.

[37] Shugart, M. and J. Carey (1992), Presidents and Assemblies: Constutional Design and Electoral Dynamics, Cambridge University Press. 
[38] Tanzi, V. and L. Schuknecht (2000), Public Spending in the 20th Century, Cambridge University Press.

[39] Treisman, D. (2000), "The causes of corruption: a cross country study", Journal of Public Economics, June, Vol. 76 n. 3, 399-458 
Table 1

Summary of Theory

\begin{tabular}{lcc}
\hline & PRES (vs. PARL) & MAJ (vs. PR) \\
\hline $\begin{array}{l}\text { Size } \\
\text { Composition } \\
\text { (welfare spending) }\end{array}$ & - & $-/ ?$ \\
\hline Deficit & - & - \\
Electoral Cycle & NA & - \\
Reaction to shock & NA & $+/ ?$ \\
\hline
\end{tabular}


Table 2

Sample of Countries

Narrow Default Broad MAJ PRES

\begin{tabular}{|c|c|c|c|c|c|}
\hline$U S A$ & $1960-98$ & $1960-98$ & $1960-98$ & 1 & 1 \\
\hline$U K$ & $1960-98$ & $1960-98$ & $1960-98$ & 1 & 0 \\
\hline AUSTRIA & $1960-98$ & $1960-98$ & $1960-98$ & 0 & 0 \\
\hline BELGIUM & $1960-98$ & $1960-98$ & $1960-98$ & 0 & 0 \\
\hline$D E N M A R K$ & $1960-98$ & $1960-98$ & $1960-98$ & 0 & 0 \\
\hline FRANCE & $1960-98$ & $1960-98$ & $1960-98$ & 0.94 & 0 \\
\hline GERMANY & $1960-98$ & 1960-98 & $1960-98$ & 0 & 0 \\
\hline$I T A L Y$ & $1960-98$ & $1960-98$ & $1960-98$ & 0 & 0 \\
\hline$L U X E M B O U R G$ & $1960-98$ & $1960-98$ & $1960-98$ & 0 & 0 \\
\hline NETHERLANDS & $1960-98$ & $1960-98$ & $1960-98$ & 0 & 0 \\
\hline$N O R W A Y$ & $1960-98$ & $1960-98$ & $1960-98$ & 0 & 0 \\
\hline SWEDEN & $1960-98$ & $1960-98$ & $1960-98$ & 0 & 0 \\
\hline SWITZERLAND & $1960-98$ & $1960-98$ & $1960-98$ & 0 & 1 \\
\hline$C A N A D A$ & $1960-98$ & $1960-98$ & $1960-98$ & 1 & 0 \\
\hline$J A P A N$ & $1960-98$ & $1960-98$ & $1960-98$ & 0 & 0 \\
\hline FINLAND & $1960-98$ & $1960-98$ & $1960-98$ & 0 & 0 \\
\hline GREECE & $1975-98$ & $1975-98$ & $1960-98$ & 0 & 0 \\
\hline ICELAND & $1960-98$ & $1960-98$ & $1960-98$ & 0 & 0 \\
\hline IRELAND & $1960-98$ & $1960-98$ & $1960-98$ & 0 & 0 \\
\hline$M A L T A$ & 1988-98 & $1960-98$ & $1960-98$ & 0 & 0 \\
\hline PORTUGAL & $1977-98$ & $1977-98$ & $1960-98$ & 0 & 0 \\
\hline$S P A I N$ & $1978-98$ & $1978-98$ & $1960-98$ & 0 & 0 \\
\hline TURKEY & - & - & $1960-98$ & 0 & 0 \\
\hline AUSTRALIA & $1960-98$ & $1960-98$ & $1960-98$ & 1 & 0 \\
\hline NEW ZEALAND & $1960-98$ & $1960-98$ & $1960-98$ & 1 & 0 \\
\hline ARGENTINA & - & 1983-98 & $1960-98$ & 0 & 1 \\
\hline BOLIVIA & - & $1982-98$ & $1960-98$ & 0 & 1 \\
\hline$B R A Z I L$ & - & $1980-98$ & $1960-98$ & 0 & 1 \\
\hline CHILE & 1991-98 & $\begin{array}{l}1960-73 \\
1989-98\end{array}$ & $1960-98$ & 1 & 1 \\
\hline COLOMBIA & - & $1960-98$ & $1960-98$ & 0 & 1 \\
\hline COSTA RICA & 1960-98 & $1960-98$ & $1960-98$ & 0 & 1 \\
\hline DOMINICAN RE & - & $1960-98$ & $1960-98$ & 0 & 1 \\
\hline$E C U A D O R$ & - & 1979-98 & $1960-98$ & 0 & 1 \\
\hline EL SALVADOR & - & $\begin{array}{l}1960-77 \\
1986-98\end{array}$ & $1960-98$ & 0 & 1 \\
\hline GUATEMALA & - & $1960-79$ & $1960-98$ & 0 & 1 \\
\hline HONDURAS & - & $1980-98$ & $1960-98$ & 0 & 1 \\
\hline MEXICO & - & $1996-98$ & $1960-98$ & 0 & 1 \\
\hline
\end{tabular}




\begin{tabular}{lccccc} 
NICARAGUA & - & - & $1960-98$ & 0 & 1 \\
PARAGUAY & - & $1990-98$ & $1960-98$ & 0 & 1 \\
PERU & - & $1981-98$ & $1960-98$ & 0 & 1 \\
URUGUAY & $1986-98$ & $1985-98$ & $1960-98$ & 0 & 1 \\
VENEZUELA & $1971-91$ & $1960-98$ & $1960-98$ & 0 & 1 \\
BAHAMAS & $1960-98$ & $1960-98$ & $1960-98$ & 1 & 0 \\
BARBADOS & $1960-98$ & $1960-98$ & $1960-98$ & 1 & 0 \\
BELIZE & $1960-98$ & $1960-98$ & $1960-98$ & 1 & 0 \\
ST.VINCENT\&G & $1960-98$ & $1960-98$ & $1960-98$ & 1 & 0 \\
TRINIDAD\&TOB & $1960-98$ & $1960-98$ & $1960-98$ & 1 & 0 \\
CYPRUS (G) & $1983-98$ & $1960-74$ & $1960-98$ & 0.31 & 0 \\
& & $1980-98$ & & & \\
ISRAEL & $1960-98$ & $1960-98$ & $1960-98$ & 0 & 0 \\
SRILANKA & - & $1960-89$ & $1960-98$ & 0 & 1 \\
INDIA & - & $1960-98$ & $1960-98$ & 1 & 0 \\
MALAYSIA & - & $1960-76$ & $1960-98$ & 1 & 0 \\
NEPAL & - & $1981-98$ & $1960-98$ & 1 & 1 \\
PHILIPPINES & - & $1985-98$ & $1960-98$ & 1 & 1 \\
SINGAPORE & - & $1981-98$ & $1960-98$ & 1 & 0 \\
THAILAND & - & $1960-98$ & $1960-98$ & 1 & 0 \\
BOTSWANA & $1990-98$ & $1960-98$ & $1960-98$ & 1 & 0 \\
GAMBIA & - & $1960-98$ & $1960-98$ & 1 & 1 \\
MAURITIUS & $1983-98$ & $1960-98$ & $1960-98$ & 1 & 0 \\
FIJI & $1960-86$ & $1960-87$ & $1960-98$ & 0 & 0 \\
PAPUA N.GUIN & $1960-86$ & $1992-98$ & & & \\
\hline & & & & & 0 \\
\hline
\end{tabular}

Narrow refers to countries with a Gastil index of political right less than 2 Default refers to countries with a Gastil index of political right less than 4 Broad refers to countries with a Gastil index of political right less than 5 
Table $3 a$

Partial Correlations

Cross Sections

\begin{tabular}{|c|c|c|c|c|c|c|c|c|c|c|}
\hline & CGEXP & SURPLUS & $S S W / G D S$ & $\overline{L Y H}$ & GASTIL & TRADE & PROP1564 & PROP65 & CENTRAL & PRES \\
\hline SURPLUS & -0.29 & & & & & & & & & \\
\hline$S S W / G D S$ & 0.47 & -0.04 & & & & & & & & \\
\hline$L Y H$ & 0.46 & 0.02 & 0.71 & & & & & & & \\
\hline GASTIL & -0.60 & 0.04 & -0.56 & -0.73 & & & & & & \\
\hline TRADE & 0.32 & 0.27 & -0.13 & 0.07 & -0.07 & & & & & \\
\hline PROP1564 & 0.44 & -0.02 & 0.72 & 0.76 & -0.61 & 0.17 & & & & \\
\hline PROP65 & 0.56 & -0.11 & 0.82 & 0.80 & -0.71 & -0.04 & 0.82 & & & \\
\hline CENTRAL & 0.16 & -0.18 & -0.51 & -0.47 & 0.34 & 0.47 & -0.43 & -0.39 & & \\
\hline PRES & -0.60 & 0.09 & -0.28 & -0.48 & 0.58 & -0.36 & -0.56 & -0.50 & 0.12 & \\
\hline$M A J$ & -0.03 & 0.23 & -0.27 & -0.12 & -0.02 & 0.23 & -0.06 & -0.22 & 0.04 & -0.24 \\
\hline
\end{tabular}




\section{Table $3 b$}

Partial Correlations

Pooled Yearly Data

\begin{tabular}{|c|c|c|c|c|c|c|c|c|c|c|}
\hline & CGEXP & SURPLUS & $S S W_{-} G D S$ & GROWTH & $L Y H$ & GASTIL & TRADE & PROP1564 & PROP65 & PRES \\
\hline SURPLUS & -0.41 & & & & & & & & & \\
\hline$S S W / G D S$ & 0.47 & -0.08 & & & & & & & & \\
\hline GROWTH & -0.15 & 0.15 & -0.18 & & & & & & & \\
\hline$L Y H$ & 0.49 & 0.01 & 0.65 & -0.11 & & & & & & \\
\hline GASTIL & -0.46 & 0.08 & -0.47 & 0.14 & -0.59 & & & & & \\
\hline TRADE & 0.32 & 0.13 & -0.13 & 0.10 & 0.13 & -0.03 & & & & \\
\hline PROP1564 & 0.44 & -0.01 & 0.60 & -0.12 & 0.76 & -0.48 & 0.19 & & & \\
\hline PROP65 & 0.56 & -0.08 & 0.79 & -0.16 & 0.79 & -0.59 & 0.02 & 0.78 & & \\
\hline PRES & -0.49 & 0.07 & -0.21 & -0.05 & -0.45 & 0.46 & -0.35 & -0.47 & -0.47 & \\
\hline$M A J$ & -0.05 & 0.12 & -0.28 & 0.05 & -0.04 & 0 & 0.16 & -0.02 & -0.17 & -0.26 \\
\hline
\end{tabular}




\section{Table 4}

\section{Size of Government}

Cross Sections

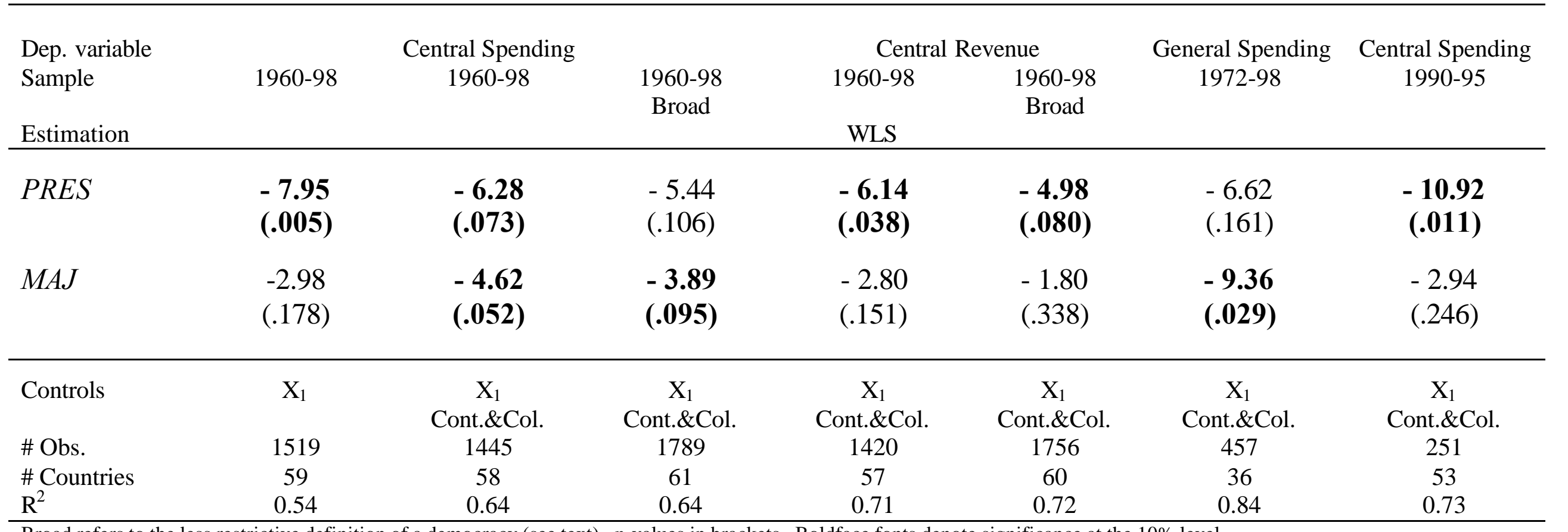

Broad refers to the less restrictive definition of a democracy (see text). $p$-values in brackets. Boldface fonts denote significance at the $10 \%$ level.

$\mathrm{X}_{1}$ includes the variables TRADE, LYH, PROP1564, PROP65 (see the text and Data Appendix).

Cont. and Col. refer to two sets of dummies for continents and colonial origin, respectively (see the Data Appendix). 


\section{Table 5}

Size of Government

Unobservable Common Events 1960-98

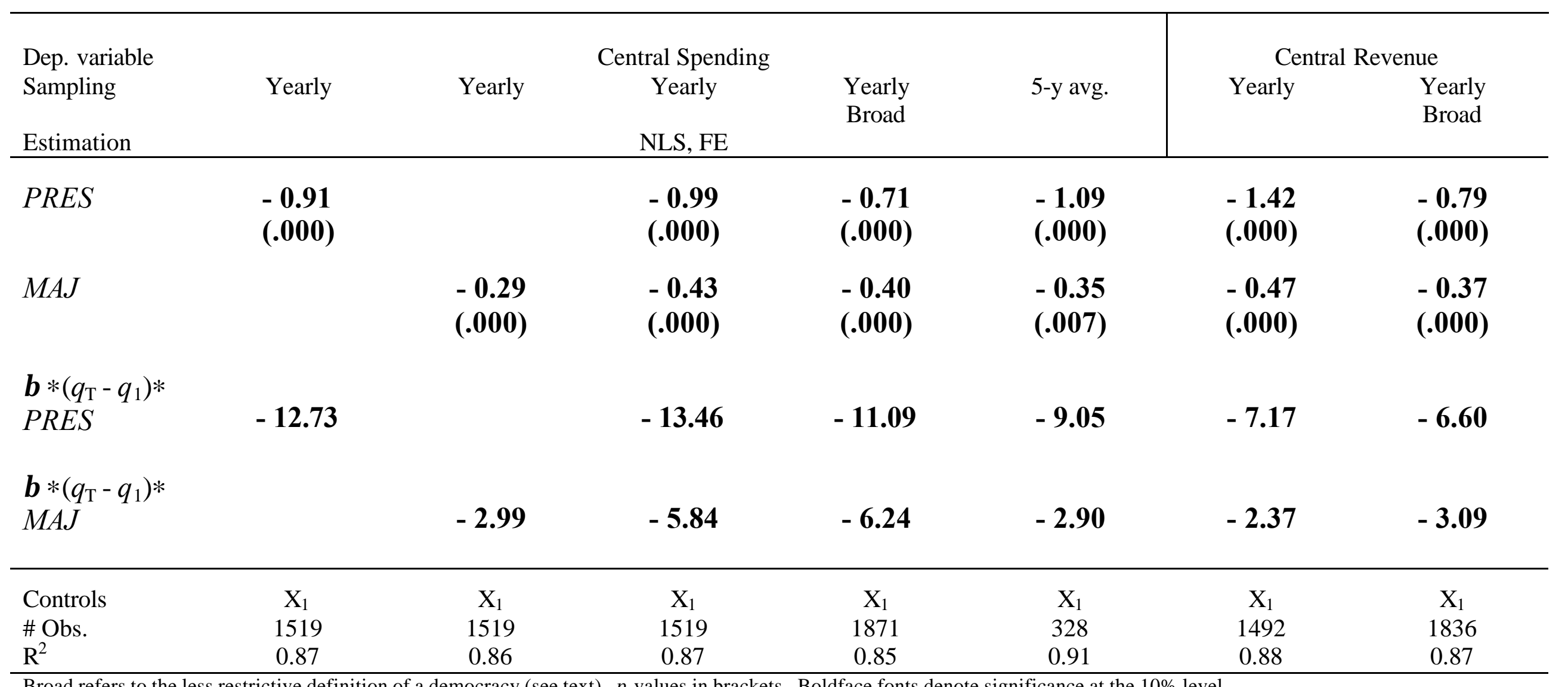

Broad refers to the less restrictive definition of a democracy (see text). $p$-values in brackets. Boldface fonts denote significance at the $10 \%$ level.

$\mathrm{X}_{1}$ includes the variables TRADE, LYH, PROP1564, PROP65 (see the text and Data Appendix). All the equations include a set of country dummies. 


\section{Table 6}

\section{Size of Central Government}

Observable Economic Events 1960-98

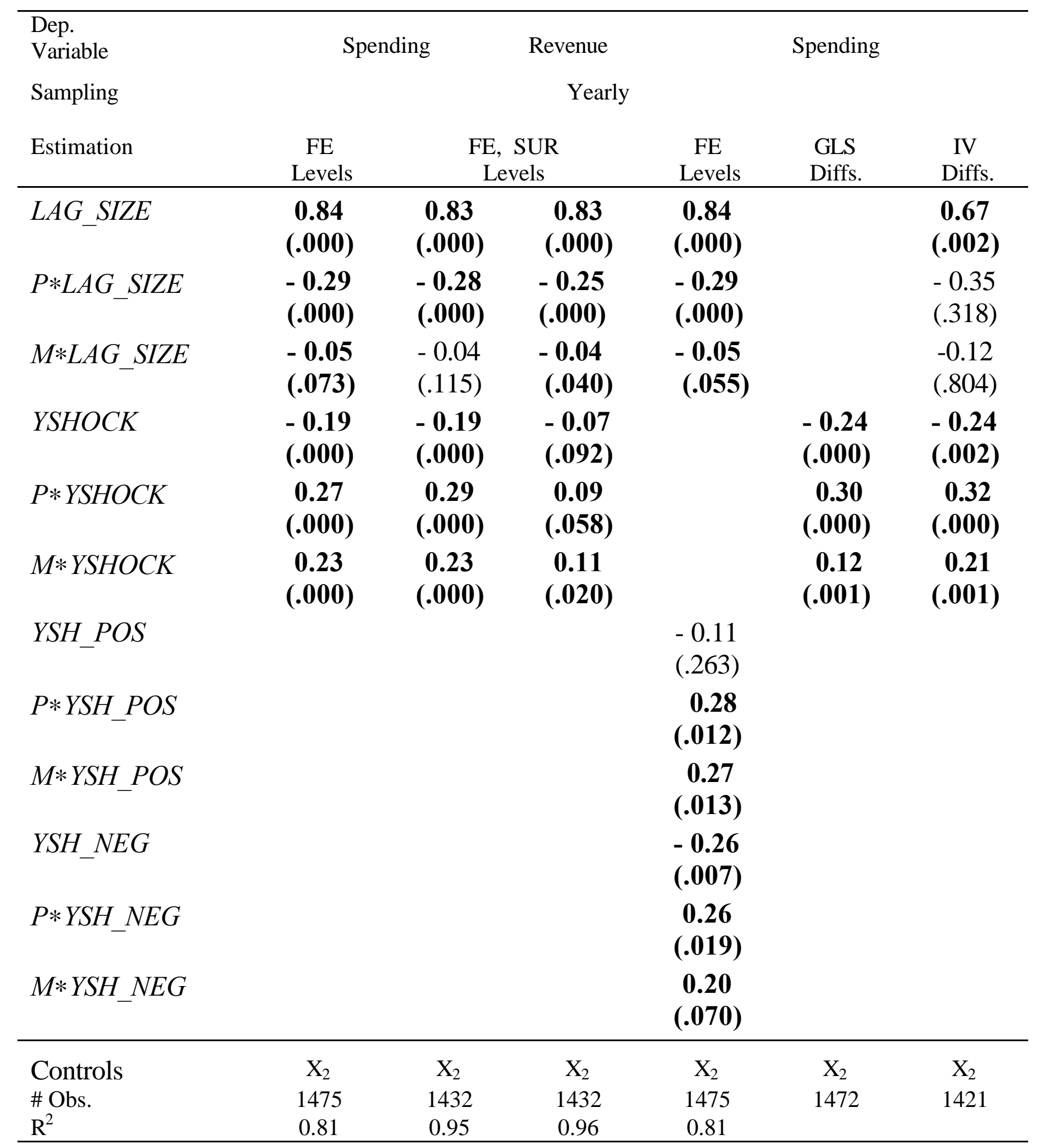

$p$-values in brackets. Boldface fonts denote significance at the $10 \%$ level.

$P$ and $M$ denote interaction with the $P R E S$ and $M A J$ dummies, respectively. $\mathrm{X}_{2}$ includes the variables in $\mathrm{X}_{1}$ (namely TRADE, LYH, PROP1564, PROP65), plus OIL and the trend corresponding to YSHOCK (see text and Data Appendix). $\mathrm{R}^{2}$ in the fixed-effects regressions refers to the within estimator. 


\section{Table 7}

Surplus of Government

Observable Economic Events 1960-98

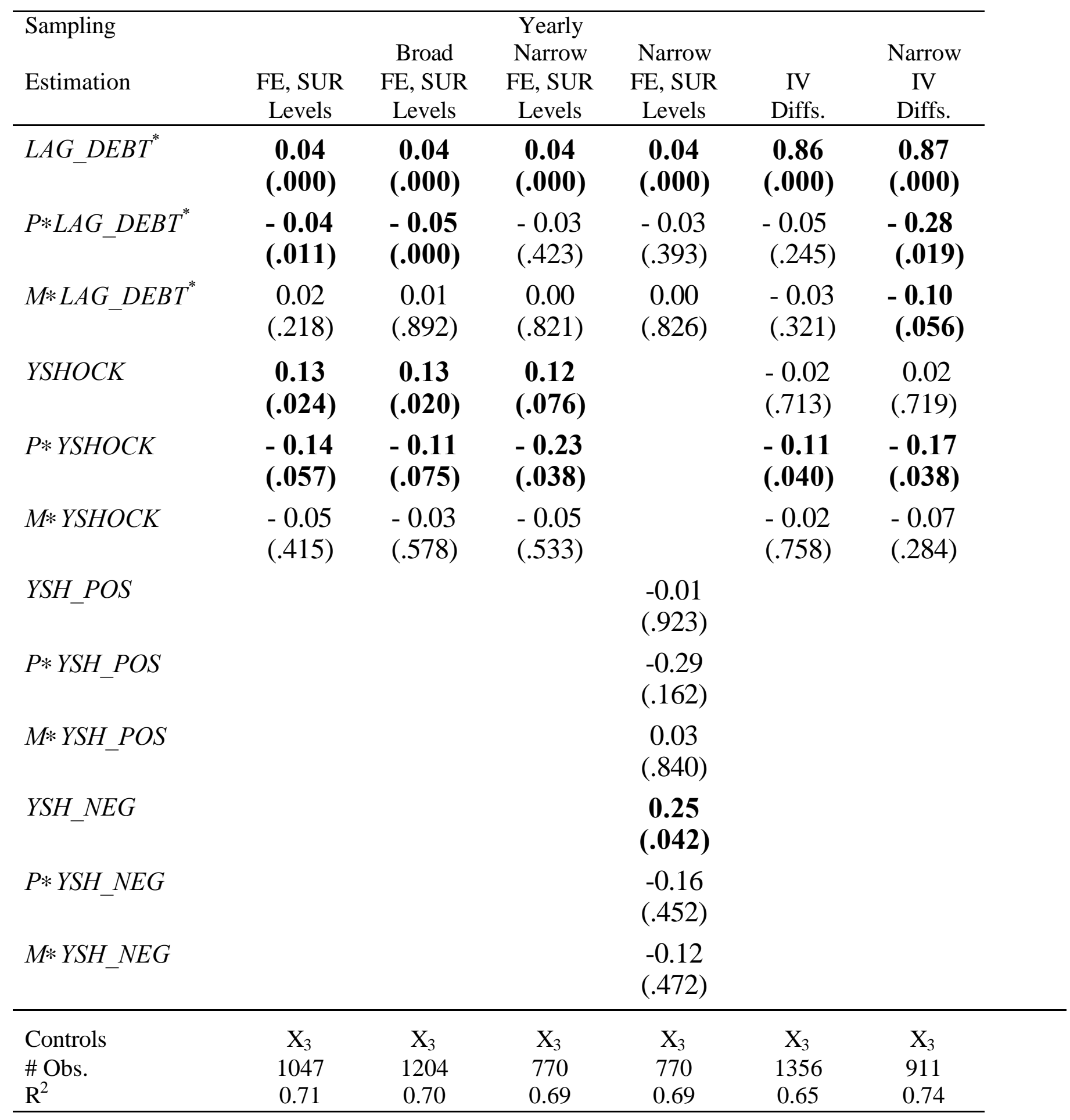

Broad and Narrow refer to less and more restrictive definitions of a democracy (see text). $p$-values in brackets.

Boldface fonts denote significance at the $10 \%$ level. SUR estimated jointly with CGEXP and CGREV

$P$ and $M$ denote interaction with the $P R E S$ and $M A J$ dummies, respectively

$\mathrm{X}_{3}$ includes the variables in $\mathrm{X}_{2}$ (namely TRADE, LYH, PROP1564,PROP65, OIL, the trend corresponding to YSHOCK) plus lagged size of spending and revenues by central government. These two variables are interacted with $P R E S$ and $M A J$ in columns $1-4$, but not in the last two columns.

$\mathrm{R}^{2}$ in the fixed-effects regressions refers to the within estimator.

* In the last two columns, the variable (change in) lagged $D E B T$ is replaced by the lagged deficit (in levels) - see the footnote in subsection 5.1. 


\section{Table 8}

Size of Government

Electoral Cycles 1960-95

\begin{tabular}{|c|c|c|c|c|c|c|c|c|}
\hline \multirow{3}{*}{$\begin{array}{l}\text { Dep. Variable } \\
\text { Sampling } \\
\text { Estimation }\end{array}$} & \multicolumn{3}{|c|}{ Central Spending } & \multicolumn{5}{|c|}{ Central Revenue } \\
\hline & & Broad & & & Broad & & & \\
\hline & $\begin{array}{c}\text { FE, SUR } \\
\text { Levels }\end{array}$ & $\begin{array}{c}\text { FE, SUR } \\
\text { Levels } \\
\end{array}$ & $\begin{array}{c}\text { IV } \\
\text { Diffs. }\end{array}$ & $\begin{array}{c}\text { FE, SUR } \\
\text { Levels }\end{array}$ & $\begin{array}{c}\text { FE, SUR } \\
\text { Levels }\end{array}$ & $\begin{array}{l}\text { IV } \\
\text { Diffs. }\end{array}$ & $\begin{array}{c}\text { FE, SUR } \\
\text { Levels }\end{array}$ & $\begin{array}{l}\text { IV } \\
\text { Diffs. }\end{array}$ \\
\hline$P R E S * E L_{t}$ & $\begin{array}{c}0.10 \\
(.784)\end{array}$ & $\begin{array}{c}0.46 \\
(.180)\end{array}$ & $\begin{array}{l}-0.23 \\
(.563)\end{array}$ & $\begin{array}{l}-0.30 \\
(.328)\end{array}$ & $\begin{array}{l}-0.11 \\
(.662)\end{array}$ & $\begin{array}{r}-0.70 \\
(.158)\end{array}$ & $\begin{array}{c}-0.75 \\
(.007)\end{array}$ & $\begin{array}{c}-0.71 \\
(.029)\end{array}$ \\
\hline$P R E S * E L_{t-1}$ & $\begin{array}{r}-0.80 \\
(.031)\end{array}$ & $\begin{array}{c}-0.98 \\
(.004)\end{array}$ & $\begin{array}{r}-1.00 \\
(.015)\end{array}$ & $\begin{array}{c}0.52 \\
(.095)\end{array}$ & $\begin{array}{c}\mathbf{0 . 4 7} \\
(.058)\end{array}$ & $\begin{array}{c}0.86 \\
(.021)\end{array}$ & $\begin{array}{c}0.19 \\
(.558)\end{array}$ & $\begin{array}{c}0.72 \\
(.047)\end{array}$ \\
\hline$P A R L * E L_{t}$ & $\begin{array}{l}-0.03 \\
(.899)\end{array}$ & $\begin{array}{c}-0.02 \\
(.932\end{array}$ & $\begin{array}{l}-0.17 \\
(.475)\end{array}$ & $\begin{array}{c}-0.31 \\
(.066)\end{array}$ & $\begin{array}{c}-0.37 \\
(.019)\end{array}$ & $\begin{array}{c}-0.44 \\
(.041)\end{array}$ & $\begin{array}{l}-0.12 \\
(.444)\end{array}$ & $\begin{array}{c}-0.37 \\
(.082)\end{array}$ \\
\hline$P A R L * E L_{t-1}$ & $\begin{array}{c}-0.11 \\
(.565) \\
\end{array}$ & $\begin{array}{l}-0.21 \\
(.345) \\
\end{array}$ & $\begin{array}{l}-0.24 \\
(.307) \\
\end{array}$ & $\begin{array}{c}0.15 \\
(.366) \\
\end{array}$ & $\begin{array}{c}0.06 \\
(.692) \\
\end{array}$ & $\begin{array}{c}0.32 \\
(.144) \\
\end{array}$ & $\begin{array}{c}0.19 \\
(.296) \\
\end{array}$ & $\begin{array}{c}0.23 \\
(.281) \\
\end{array}$ \\
\hline $\begin{array}{l}\text { Controls } \\
\text { \# Obs. } \\
\mathrm{R}^{2} \\
\end{array}$ & $\begin{array}{c}\mathrm{X}_{4} \\
1350 \\
0.95 \\
\end{array}$ & $\begin{array}{c}\mathrm{X}_{4} \\
1670 \\
0.95 \\
\end{array}$ & $\begin{array}{c}\mathrm{X}_{4} \\
1339\end{array}$ & $\begin{array}{c}X_{5} \\
1350 \\
0.96 \\
\end{array}$ & $\begin{array}{c}X_{5} \\
1670 \\
0.96 \\
\end{array}$ & $\begin{array}{c}\mathrm{X}_{5} \\
1316\end{array}$ & $\begin{array}{c}X_{5} \\
1390 \\
0.96 \\
\end{array}$ & $\begin{array}{c}\mathrm{X}_{5} \\
1355\end{array}$ \\
\hline
\end{tabular}

Broad refers to the less restrictive definition of a democracy (see Table 2). $p$-values in brackets. Boldface fonts denote significance at the $10 \%$ level.

$E L_{t}$ and $E L_{t-1}$ are dummy variables for the election and post-election years, respectively.

$\mathrm{X}_{4}$ includes the variables in $\mathrm{X}_{2}$ minus $O I L$ and all the variables (including the interaction terms) in column 1 of Table 6, plus a set

of year dummies; $\mathrm{X}_{5}$ is constructed as $\mathrm{X}_{4}$ but with lagged central revenue taking the place of lagged central spending (see the text and Appendix).

Note that $E L_{t}$ in the last two columns is defined as to take a value of 1 not only in the election year but also in the year before. 
Table 9

Surplus of Government

Electoral Cycles 1960-95

\begin{tabular}{|c|c|c|c|c|c|c|}
\hline Sample & & & & Broad & Narrow & \\
\hline Estimation & $\begin{array}{c}\mathrm{FE} \\
\text { Levels }\end{array}$ & $\begin{array}{c}\text { FE, SUR } \\
\text { Levels }\end{array}$ & $\begin{array}{c}\text { IV } \\
\text { Diffs. }\end{array}$ & $\begin{array}{c}\text { IV } \\
\text { Diffs. }\end{array}$ & $\begin{array}{c}\text { IV } \\
\text { Diffs. }\end{array}$ & $\begin{array}{c}\text { GLS } \\
\text { Diffs. }\end{array}$ \\
\hline$P R E S * E L_{t}$ & $\begin{array}{c}-0.18 \\
(.718)\end{array}$ & $\begin{array}{c}-0.16 \\
(.740)\end{array}$ & $\begin{array}{l}-0.29 \\
(.425)\end{array}$ & $\begin{array}{c}-0.38 \\
(.201)\end{array}$ & $\begin{array}{c}-0.29 \\
(.620)\end{array}$ & $\begin{array}{c}0.12 \\
(.429)\end{array}$ \\
\hline$P R E S * E L_{t-1}$ & $\begin{array}{c}0.58 \\
(.244)\end{array}$ & $\begin{array}{c}0.65 \\
(.170)\end{array}$ & $\begin{array}{c}0.86 \\
(.015)\end{array}$ & $\begin{array}{c}1.14 \\
(.000)\end{array}$ & $\begin{array}{c}1.02 \\
(.089)\end{array}$ & $\begin{array}{r}0.69 \\
(.000)\end{array}$ \\
\hline$P A R L * E L_{t}$ & $\begin{array}{l}-0.02 \\
(.926)\end{array}$ & $\begin{array}{l}-0.01 \\
(.976)\end{array}$ & $\begin{array}{l}-0.01 \\
(.978)\end{array}$ & $\begin{array}{l}-0.10 \\
(.581)\end{array}$ & $\begin{array}{c}-0.12 \\
(.513)\end{array}$ & $\begin{array}{r}-0.16 \\
(.046)\end{array}$ \\
\hline$P A R L * E L_{t-1}$ & $\begin{array}{c}0.24 \\
(.264) \\
\end{array}$ & $\begin{array}{c}0.25 \\
(.209)\end{array}$ & $\begin{array}{c}0.05 \\
(.805)\end{array}$ & $\begin{array}{c}0.04 \\
(.823)\end{array}$ & $\begin{array}{c}0.49 \\
(.033)\end{array}$ & $\begin{array}{c}-0.14 \\
(.087)\end{array}$ \\
\hline $\begin{array}{l}\text { Controls } \\
\text { \# Obs. } \\
\mathrm{R}^{2}\end{array}$ & $\begin{array}{c}X_{6} \\
1003 \\
0.46\end{array}$ & $\begin{array}{c}X_{6} \\
1002 \\
0.74\end{array}$ & $\begin{array}{c}\mathrm{X}_{6} \\
1281 \\
0.71\end{array}$ & $\begin{array}{c}X_{6} \\
1569 \\
0.68\end{array}$ & $\begin{array}{c}\mathrm{X}_{6} \\
872 \\
0.77\end{array}$ & $\begin{array}{c}\mathrm{X}_{7} \\
1425\end{array}$ \\
\hline
\end{tabular}

Broad and Narrow refer to the less and more restrictive definitions of a democracy (see text). $p$-values in brackets. Boldface fonts denote significance at the $10 \%$ level. $E L_{t}$ and $E L_{t-1}$ are dummy variables for the election and post-election years, respectively. SUR estimated together with $C G E X P$ and $C G R E V$.

$\mathrm{X}_{6}$ includes the variables in $\mathrm{X}_{2}$ except $O I L$ plus all the variables (including the interaction terms) in Column 1 of Table 7

plus a set of yearly dummies; $\mathrm{X}_{7}$ is identical to $\mathrm{X}_{6}$ except that the lagged surplus is not included (see the text).

$\mathrm{R}^{2}$ in the fixed-effects regressions refers to the within estimator. 
Table 10

\section{Composition of Government}

Cross Sections 1972-98

\begin{tabular}{|c|c|c|c|c|c|c|}
\hline Dep. Variable & & SSW/GDP & & & SSW/GDS & \multirow[b]{2}{*}{ Broad } \\
\hline $\begin{array}{l}\text { Sample } \\
\text { Estimation }\end{array}$ & \multicolumn{3}{|r|}{ Broad } & & & \\
\hline PRES & $\begin{array}{r}-0.70 \\
(.583)\end{array}$ & $\begin{array}{l}-2.13 \\
(.229)\end{array}$ & $\begin{array}{l}-0.75 \\
(.642)\end{array}$ & $\begin{array}{c}0.15 \\
(.442)\end{array}$ & $\begin{array}{c}0.13 \\
(.591)\end{array}$ & $\begin{array}{c}0.22 \\
(.323)\end{array}$ \\
\hline$M A J$ & $\begin{array}{r}-2.30 \\
(.031)\end{array}$ & $\begin{array}{l}-2.41 \\
(.062)\end{array}$ & $\begin{array}{l}-1.86 \\
(.122)\end{array}$ & $\begin{array}{l}-0.25 \\
(.117)\end{array}$ & $\begin{array}{c}-0.47 \\
(.022)\end{array}$ & $\begin{array}{r}-0.35 \\
(.050)\end{array}$ \\
\hline Controls & $\mathrm{X}_{1}$ & $\begin{array}{c}\mathrm{X}_{1} \\
\text { Cont.\&Col. }\end{array}$ & $\begin{array}{c}\mathrm{X}_{1} \\
\text { Cont.\&Col. }\end{array}$ & $\mathrm{X}_{1}$ & $\begin{array}{c}\mathrm{X}_{1} \\
\text { Cont.\&Col. }\end{array}$ & $\begin{array}{c}\mathrm{X}_{1} \\
\text { Cont.\&Col. }\end{array}$ \\
\hline \# Obs. & 901 & 865 & 1063 & 881 & 845 & 1040 \\
\hline \# Countries & 55 & 54 & 59 & 53 & 52 & 57 \\
\hline $\mathrm{R}^{2}$ & 0.77 & 0.80 & 0.79 & 0.69 & 0.74 & 0.74 \\
\hline
\end{tabular}

Broad refers to the less restrictive definition of a democracy (see text). $p$-values in brackets. Boldface fonts denote significance at the $10 \%$ level.

$\mathrm{X}_{1}$ includes the variables TRADE, LYH, PROP1564, PROP 65 (see the text and Data Appendix).

Cont. and Col. refer to two sets of dummies for continents and colonial origin, respectively (see the Data Appendix). 
Table 11

Composition of Government

Unobservable Common Events 1972-98

\begin{tabular}{|c|c|c|c|c|c|c|}
\hline \multirow{3}{*}{$\begin{array}{c}\text { Dep. variable } \\
\text { Sampling } \\
\text { Estimation }\end{array}$} & \multicolumn{3}{|c|}{ SSW/GDP } & \multicolumn{3}{|c|}{ SSW/GDS } \\
\hline & Yearly & Yearly & $\begin{array}{l}\text { Yearly } \\
\text { Broad }\end{array}$ & Yearly & Yearly & $\begin{array}{l}\text { Yearly } \\
\text { Broad }\end{array}$ \\
\hline & \multicolumn{6}{|c|}{ NLS, FE } \\
\hline PRES & $\begin{array}{c}-0.63 \\
(.000)\end{array}$ & $\begin{array}{r}-0.66 \\
(.000)\end{array}$ & $\begin{array}{l}-0.69 \\
(.000)\end{array}$ & & $\begin{array}{r}-0.38 \\
(.002)\end{array}$ & $\begin{array}{c}-0.18 \\
(.089)\end{array}$ \\
\hline$M A J$ & & $\begin{array}{r}-0.14 \\
(.028)\end{array}$ & $\begin{array}{l}-0.12 \\
(.080)\end{array}$ & $\begin{array}{l}-0.28 \\
(.017)\end{array}$ & $\begin{array}{l}-0.24 \\
(.023)\end{array}$ & $\begin{array}{l}-0.20 \\
(.056)\end{array}$ \\
\hline $\begin{array}{c}\beta *\left(q_{T}-q_{1}\right) * \\
P R E S\end{array}$ & -4.70 & -4.92 & -4.04 & & -0.13 & -0.07 \\
\hline $\begin{array}{c}\beta *\left(q_{T}-q_{1}\right) * \\
M A J\end{array}$ & & -1.04 & -0.70 & -0.14 & -0.20 & -0.08 \\
\hline Controls & $\mathrm{X}_{1}$ & $\mathrm{X}_{1}$ & $\mathrm{X}_{1}$ & $\mathrm{X}_{1}$ & $\mathrm{X}_{1}$ & $\mathrm{X}_{1}$ \\
\hline \# Obs. & 901 & 901 & 1104 & 881 & 881 & 1081 \\
\hline $\mathrm{R}^{2}$ & 0.96 & 0.96 & 0.96 & 0.95 & 0.95 & 0.95 \\
\hline
\end{tabular}


Table 12

Composition of Government

Observable Economic Events 1972-98

\begin{tabular}{|c|c|c|c|c|c|c|c|}
\hline $\begin{array}{l}\text { Dep. } \\
\text { variable }\end{array}$ & & & & SSW/GDP & & & \\
\hline Sampling & Yearly & Yearly & $\begin{array}{l}\text { Yearly } \\
\text { Narrow }\end{array}$ & $\begin{array}{l}\text { Yearly } \\
\text { Broad }\end{array}$ & Yearly & $\begin{array}{c}\text { Yearly } \\
\text { Narrow }\end{array}$ & $\begin{array}{l}\text { Yearly } \\
\text { Broad }\end{array}$ \\
\hline Estimation & $\begin{array}{c}\mathrm{FE} \\
\text { Levels }\end{array}$ & $\begin{array}{c}\text { FE, SUR } \\
\text { Levels }\end{array}$ & $\begin{array}{c}\text { FE, SUR } \\
\text { Levels }\end{array}$ & $\begin{array}{c}\text { FE, SUR } \\
\text { Levels }\end{array}$ & $\begin{array}{c}\text { IV } \\
\text { Diffs. }\end{array}$ & $\begin{array}{l}\text { IV } \\
\text { Diffs. }\end{array}$ & $\begin{array}{l}\text { IV } \\
\text { Diffs. }\end{array}$ \\
\hline$L A G \_C O M$ & $\begin{array}{c}0.81 \\
(.000)\end{array}$ & $\begin{array}{c}\mathbf{0 . 8 1} \\
(.000)\end{array}$ & $\begin{array}{c}0.81 \\
(.000)\end{array}$ & $\begin{array}{c}\mathbf{0 . 8 0} \\
(.000)\end{array}$ & $\begin{array}{c}0.39 \\
(.001)\end{array}$ & $\begin{array}{c}0.39 \\
(.001)\end{array}$ & $\begin{array}{c}0.33 \\
(.009)\end{array}$ \\
\hline$P * L A G \_C O M$ & $\begin{array}{c}-0.03 \\
(.524)\end{array}$ & $\begin{array}{l}-0.05 \\
(.180)\end{array}$ & $\begin{array}{c}-0.03 \\
(.556)\end{array}$ & $\begin{array}{l}-0.04 \\
(.212)\end{array}$ & $\begin{array}{c}-0.58 \\
(.182)\end{array}$ & $\begin{array}{c}0.06 \\
(.862)\end{array}$ & $\begin{array}{c}-\mathbf{0 . 6 3} \\
(\mathbf{. 0 3 0})\end{array}$ \\
\hline$M * L A G \_C O M$ & $\begin{array}{c}-\mathbf{- 0 . 0 6} \\
\mathbf{( . 0 2 7 )}\end{array}$ & $\begin{array}{r}-0.07 \\
(.004)\end{array}$ & $\begin{array}{l}-0.04 \\
(.128)\end{array}$ & $\begin{array}{l}-0.04 \\
(.122)\end{array}$ & $\begin{array}{r}-0.49 \\
(.076)\end{array}$ & $\begin{array}{r}-0.32 \\
(.201)\end{array}$ & $\begin{array}{l}-0.22 \\
(.430)\end{array}$ \\
\hline$Y S H O C K$ & $\begin{array}{c}-0.11 \\
(.000)\end{array}$ & $\begin{array}{c}-0.11 \\
(.000)\end{array}$ & $\begin{array}{c}-0.13 \\
(.000)\end{array}$ & $\begin{array}{c}-0.08 \\
(.000)\end{array}$ & $\begin{array}{c}-0.10 \\
(.000)\end{array}$ & $\begin{array}{c}-0.12 \\
(.001)\end{array}$ & $\begin{array}{c}-0.64 \\
(.005)\end{array}$ \\
\hline$P * Y S H O C K$ & $\begin{array}{c}0.05 \\
(.026)\end{array}$ & $\begin{array}{c}0.05 \\
(.022)\end{array}$ & $\begin{array}{c}0.04 \\
(.303)\end{array}$ & $\begin{array}{c}0.06 \\
(.001)\end{array}$ & $\begin{array}{c}0.08 \\
(.000)\end{array}$ & $\begin{array}{c}0.09 \\
(.016)\end{array}$ & $\begin{array}{c}\mathbf{0 . 0 3} \\
(.055)\end{array}$ \\
\hline$M * Y S H O C K$ & $\begin{array}{c}\mathbf{0 . 0 7} \\
(.002)\end{array}$ & $\begin{array}{c}0.07 \\
(.001)\end{array}$ & $\begin{array}{c}0.07 \\
(.029)\end{array}$ & $\begin{array}{c}0.03 \\
(.114)\end{array}$ & $\begin{array}{c}0.09 \\
(.000)\end{array}$ & $\begin{array}{c}0.10 \\
(.001)\end{array}$ & $\begin{array}{c}\mathbf{0 . 0 4} \\
(.037)\end{array}$ \\
\hline Controls & $\mathrm{X}_{2}$ & $\mathrm{X}_{2}$ & $X_{2}$ & $\mathrm{X}_{2}$ & $\mathrm{X}_{2}$ & $X_{2}$ & $\mathrm{X}_{2}$ \\
\hline \# Obs. & 847 & 847 & 616 & 1031 & 789 & 578 & 953 \\
\hline $\mathrm{R}^{2}$ & 0.77 & 0.99 & 0.98 & 0.98 & 0.05 & 0.05 & 0.03 \\
\hline
\end{tabular}

Broad refers to the less restrictive definition of a democracy (see Table 2). SUR is jointly estimated with CGEXP. $p$-values in brackets.Boldface fonts denote significance at the $10 \%$ level.

$P$ and $M$ denote interaction with the $P R E S$ and $M A J$ dummies, respectively

$\mathrm{X}_{2}$ includes the same variables as $\mathrm{X}_{1}$ (namely TRADE, LYH, PROP1564, PROP65), plus OIL and the income trend corresponding to YSHOCK

$\mathrm{R}^{2}$ in the fixed-effects regression refers to the within estimator. 
Table 13

Composition of Government

Electoral Cycles 1972-95

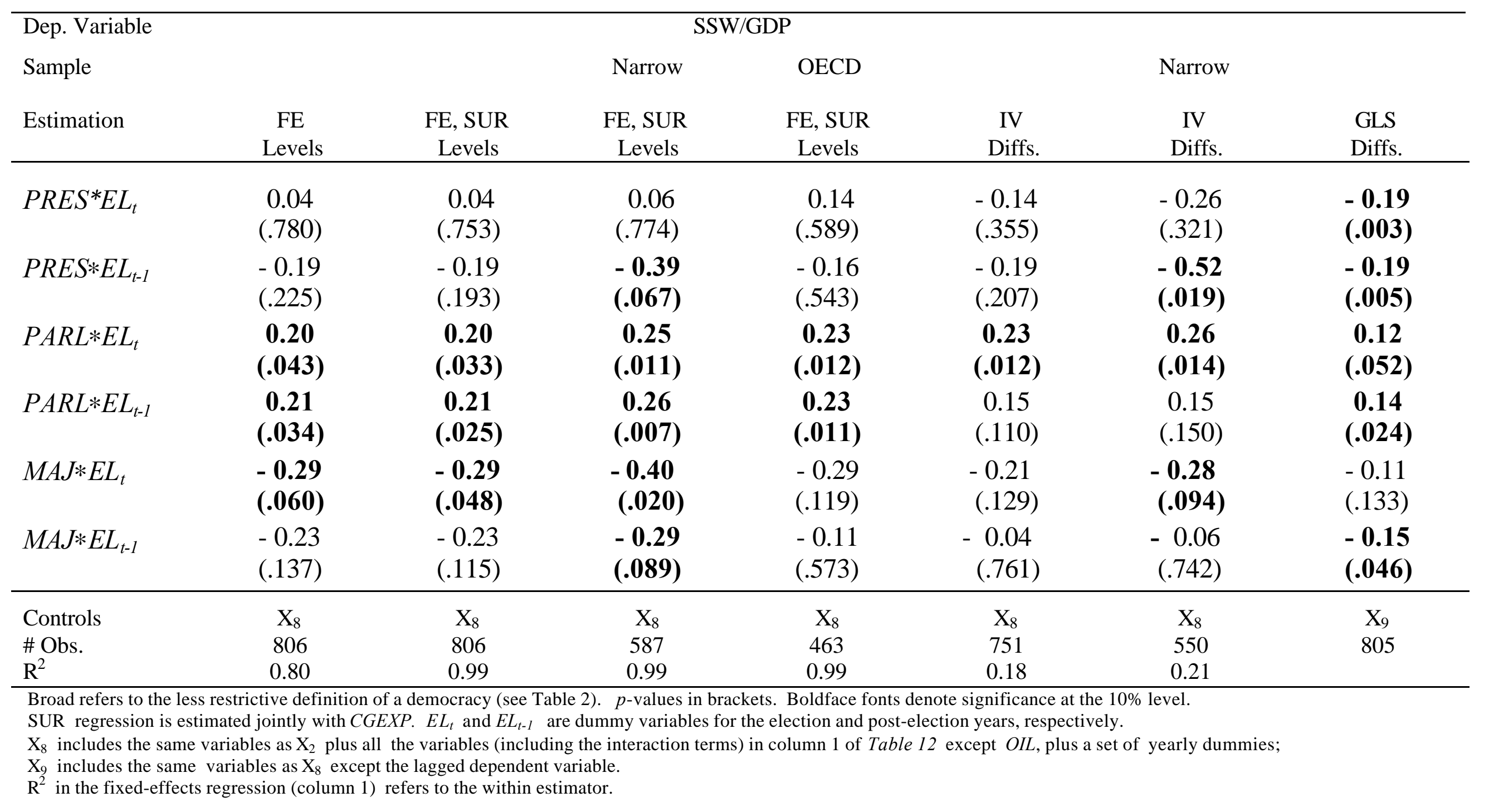


Table 14

Summary of Results

\begin{tabular}{lcccc}
\hline & \multicolumn{2}{c}{$P R E S($ vs. $P A R L)$} & \multicolumn{2}{c}{$M A J(\mathrm{vs.} P R)$} \\
& Evidence & Theory & Evidence & Theory \\
\hline $\begin{array}{l}\text { Size } \\
\begin{array}{l}\text { Composition } \\
\text { (welfare spending) }\end{array}\end{array}$ & - & - & $-/ 0$ & $-/ ?$ \\
\hline Electoral cycle & $-/ 0$ & - & - & - \\
Reaction to shocks & - & NA & 0 & $+/ ?$ \\
& & NA & - & NA \\
\hline
\end{tabular}


Figure 1

Political Institutions 1995

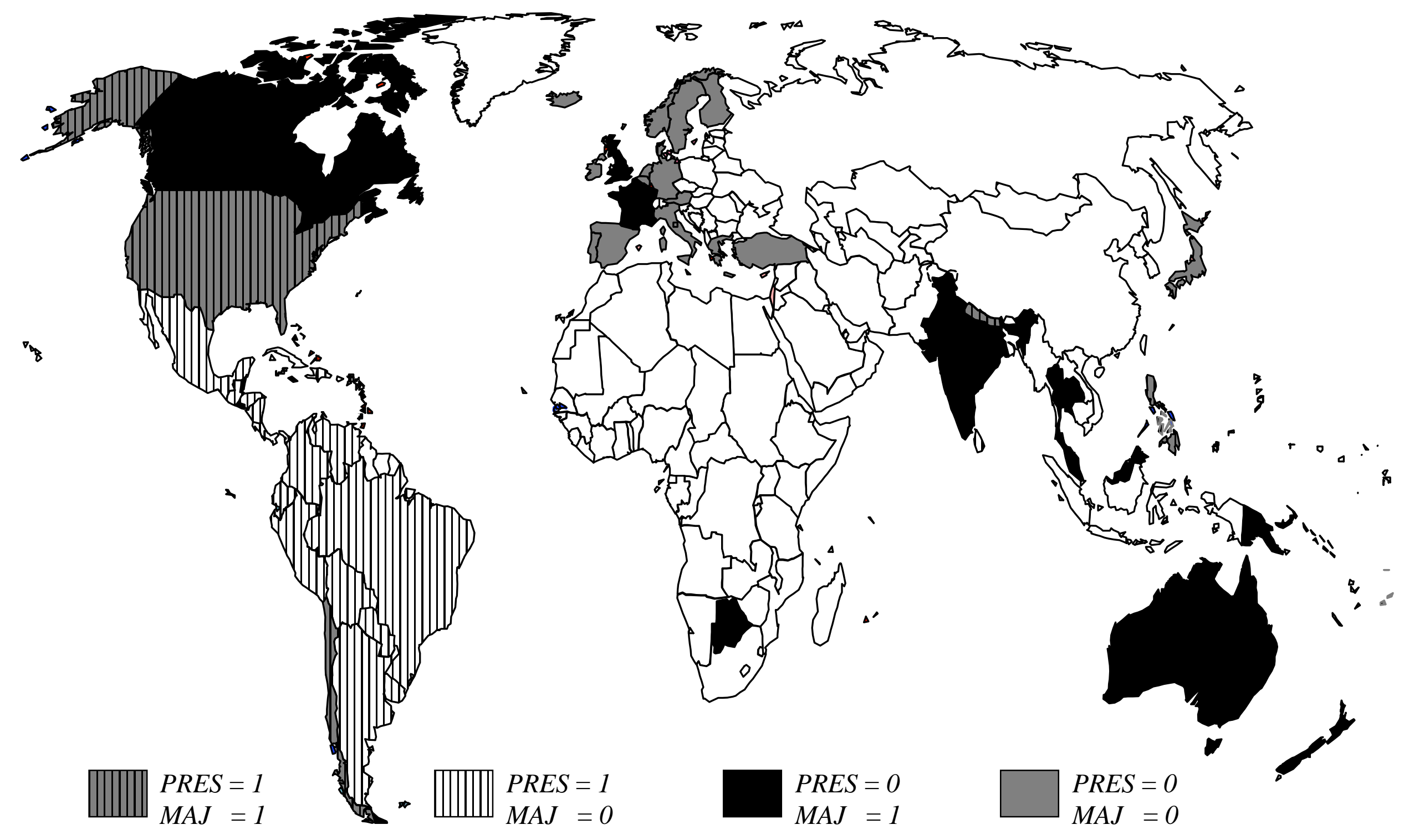


Figure 2

Size of Government 1960-98

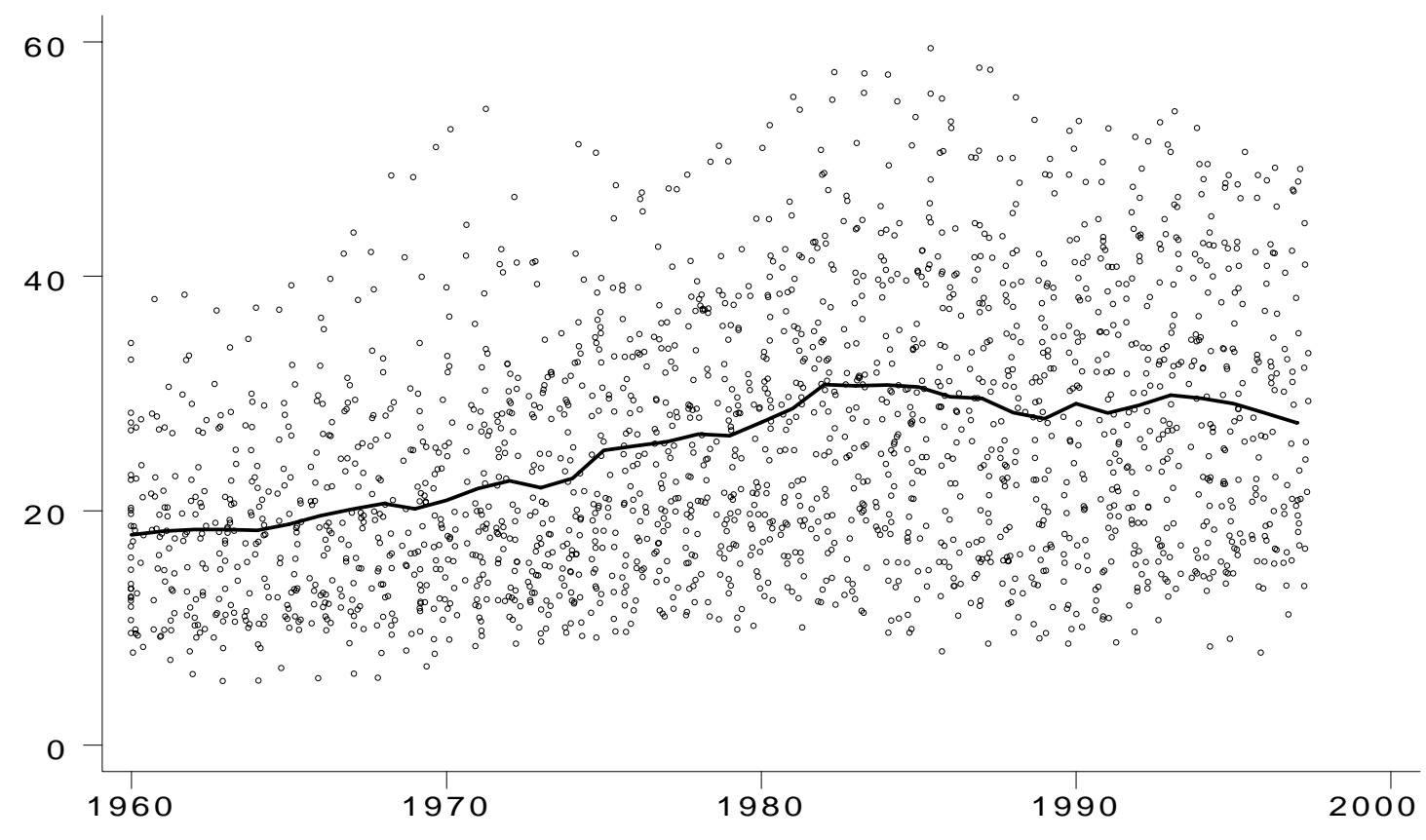


Figure 3

Size of Government 1960-98

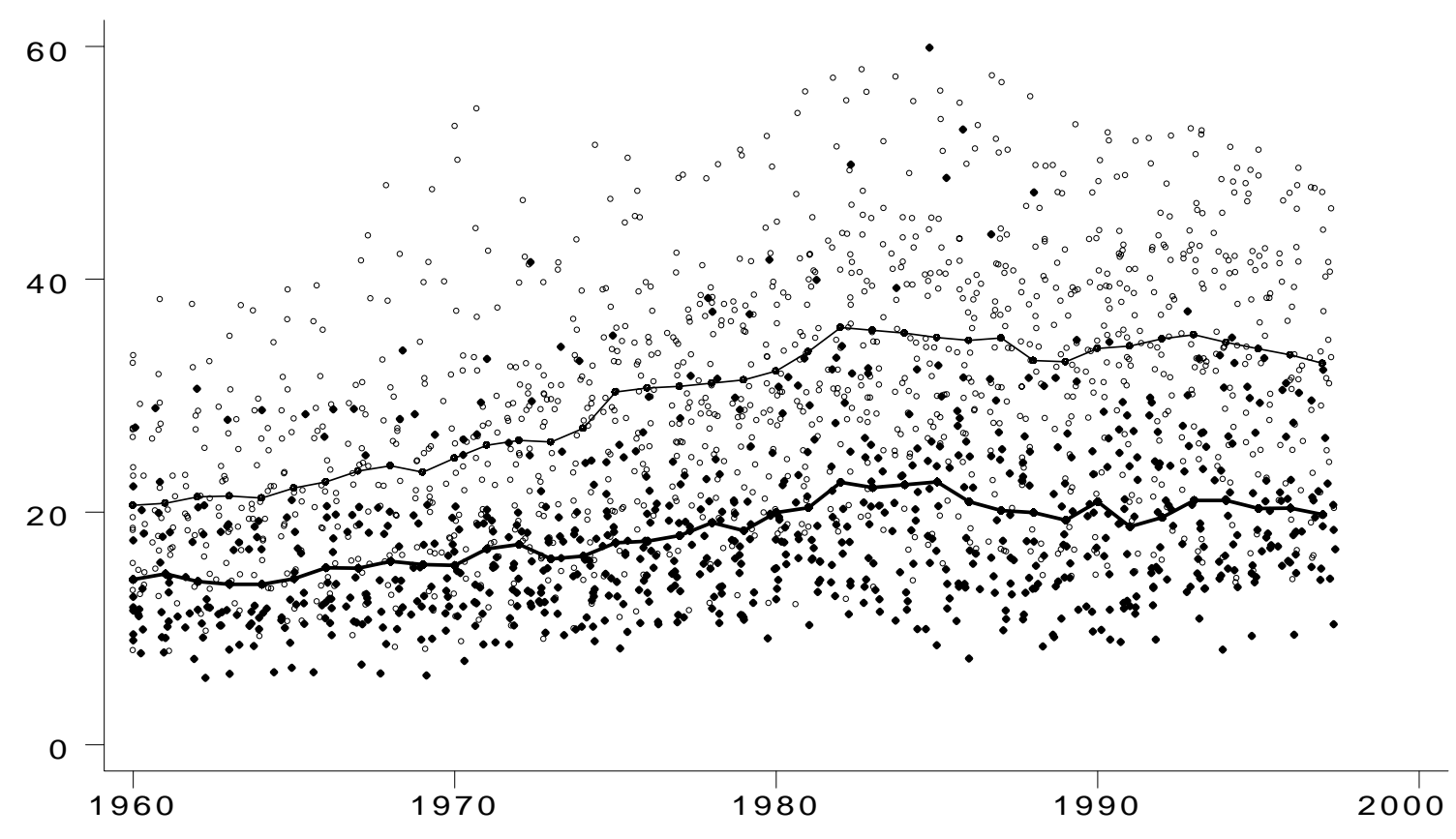


Figure 4

Adjustment to Common Unobserved Events

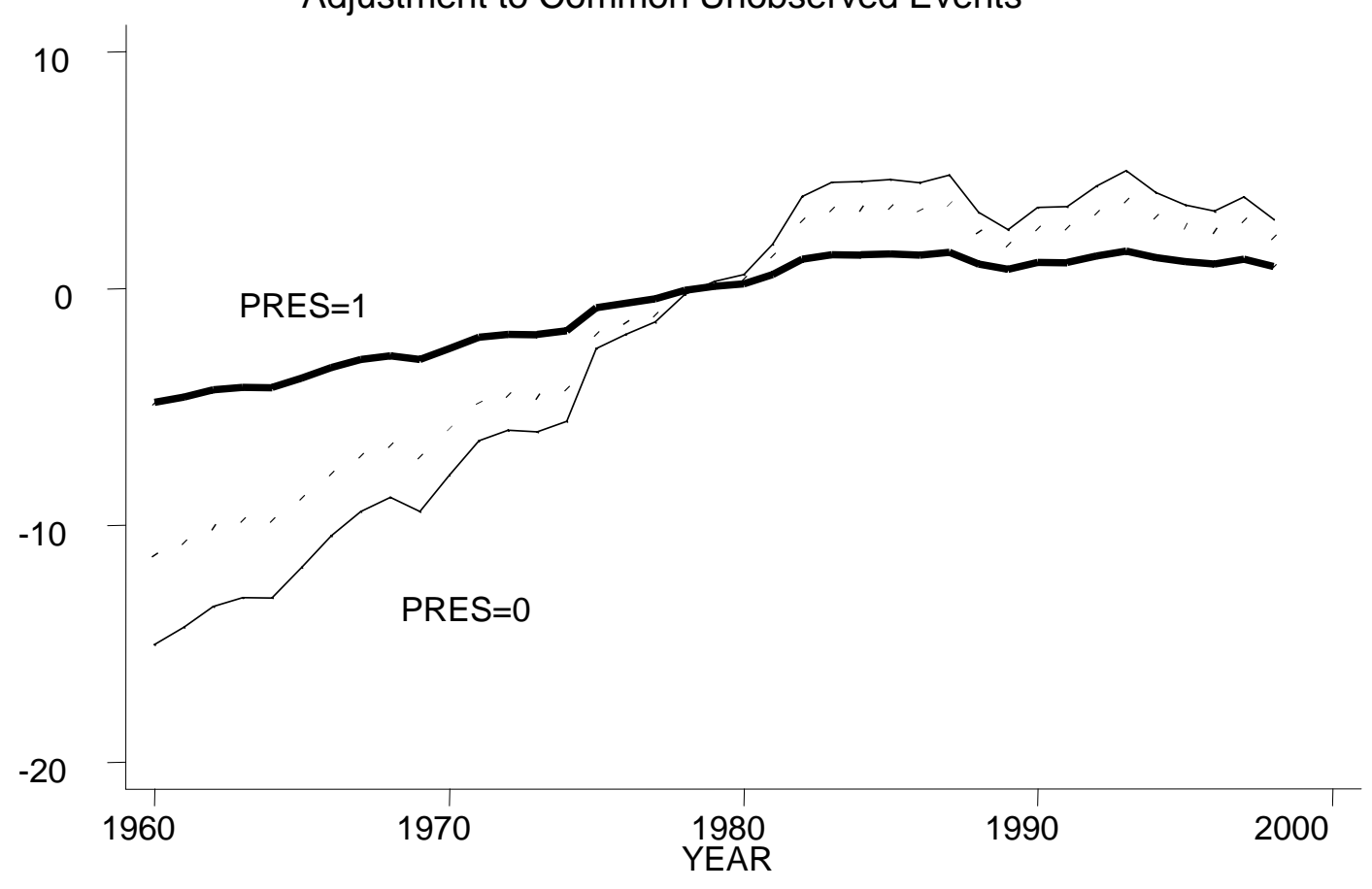




\section{DATA APPENDIX}

CENTRAL: Degree of centralization of spending, measured as the ratio between central and general government expenditure. Source: GFS and IFS, International Monetary Fund

CGEXP: Central Government Expenditure (as a percentage of GDP) Source: IFS, International Monetary Fund.

CGREV: Central Government Revenue (as a percentage of GDP) Source: IFS, International Monetary Fund.

COLONIAL ORIGIN: Three dummy variables, COLO_UK, COLO_ES, and COLO_OTH, for countries with colonial origins in the UK, Spain or Portugal, and other colonizers, respectively. Source: CIA World Factbook 1998.

CONTINENTS: Four dummy variables, ASIA, AFRICA, LAAM, OECD, for different continents or levels of development. Source: Persson and Tabellini (1999).

DEBT: Total government debt (both domestic and foreign) as a percentage of GDP. Source: IFS, International Monetary Fund.

ELECTION: Takes value of 1 when the parliamentary/presidential election is held, 0 otherwise. When the country is considered as parliamentary we use legislative elections, otherwise presidential elections. For elections of the legislature, only elections for the lower or single house are considered. Partial elections that cover at least $1 / 3$ of the total seats available are recorded as 1. For presidential regimes, only first round elections for president are considered. Sources: International Institute for Democracy and Electoral Assistance (2000) and Inter Parliamentary Union (Chronicle of Parliamentary Elections, various issues). Political Handbook of the World, different volumes (from 1960 to 1996) Banks (Ed.) and Muller (Ed.); Mackie and Rose "The International Almanac of Electoral History" Mc Millan.

GASTIL: Average of Gastil index for civil liberties and political rights. Source: Freedom House, various years.

GGEXP: General Government Expenditure (as a percentage of GDP) Source: GFS, International Monetary Fund

LYH: Real GDP Per Capita in constant dollars (international prices, base year 1985), expressed in logs. Source: Penn World Table 5.6. Missing data calculated from 1985 GDP per capita and GDP per capita growth rates (Global Development Finance \& World Development Indicators).

MAJ: Dummy variable taking value 1 if the country's electoral system in that year utilizes a majority or plurality rule for legislative elections, 0 otherwise. Source: Inter Parliamentary Union, various years. 
OIL: Oil Price (Market Price-Petroleum, Spot US \$/Barrel) avg. crude price not seasonally adjusted. Source: IMF, International Financial Statistics.

PRES: Dummy variable taking a value of 1 for presidential regimes. Sources: Shugart., M. and J. Carey (1992), "Presidents and Assemblies", Cambridge University Press (in particular fig 8.2); Cox, G., (1997) "Making Votes Count”, Cambridge University Press (appendix C); Delury, G. (Ed.) (1983), World Encyclopedia of Political Systems.

PROP1564: Share of total population between 15 and 64 years of age. Source: World Saving Database, World Bank.

PROP65: Share of population older than 65. Source: World Saving Database, World Bank.

SSW/GDP: Central Government Expenditures on social security and welfare (as a percentage of GDP) Source: GFS, International Monetary Fund.

SSW/GDS: Central Government Expenditures on social security and welfare (as a percentage of GDP) divided by Central Government Current Expenditure on goods and services (as a percentage of GDP) Source GFS, International Monetary Fund.

SURPLUS: Overall surplus (as a percentage of GDP) Source: IFS, International Monetary Fund.

TRADE: Total trade (imports +exports) (as a percentage of GDP). Source: Global Development Finance \& World Development Indicators.

YSHOCK: Log deviation of real GDP from its HP filtered trend. Real GDP is measured in constant dollars (international prices, base year 1985). Source: Penn World Tables

YTREND: HP-filtered trend value of real GDP (see YSHOCK). 